IFN Working Paper No. 1007, 2014

\title{
Globalization and the Transmission of Social Values: The Case of Tolerance
}

Niclas Berggren and Therese Nilsson 


\title{
Globalization and the Transmission of Social Values: The Case of Tolerance $^{*}$
}

\author{
Niclas Berggren $^{\S}$ and Therese Nilsson ${ }^{\#}$
}

\begin{abstract}
Tolerance - respecting those who are different - is arguably of particular importance in an era of globalization, where a potential for economic, social and personal development is increasingly a function of interaction with others different from oneself. We investigate whether globalization induces parents to want to instill tolerance in their children, the main idea being that this would equip the latter for greater success in a more integrated world. We indeed find, using a willingness-to-teach-kids-tolerance measure, that globalization enhances the willingness to transmit such social values. More precisely, economic and social, but not political, globalization has this effect, as shown by using the KOF Index of Globalization in cross-sectional and panel-data regression analyses of up to 66 countries. Addressing potential endogeneity concerns using an instrumental variables approach moreover suggests these relationships to be causal. Overall, our results confirm that certain kinds of globalization seem able to shape values in ways considered desirable by many.
\end{abstract}

Keywords. Globalization, Tolerance, Social values, Children, Welfare state

JEL Codes. F01, F10, P45, Z13

\footnotetext{
* We wish to thank Christian Bjørnskov and Lina Maria Ellegård for valuable comments, Olga Pugatsova for excellent research assistance, and Johan och Jakob Söderbergs Stiftelse (Berggren), the Swedish Research Council (Berggren and Nilsson), the Jan Wallander and Tom Hedelius Foundation (Berggren and Nilsson), and Stiftelsen Partnerskapet, Lund University (Nilsson) for financial support.

$\S$ Research Institute of Industrial Economics (IFN), P.O. Box 55665, SE-102 15 Stockholm, Sweden; and Department of Institutional Economics, University of Economics in Prague. E-mail: niclas.berggren@ifn.se.

${ }^{*}$ Research Institute of Industrial Economics (IFN), P.O. Box 55665, SE-102 15 Stockholm, Sweden, and Department of Economics, Lund University, Sweden; and. E-mail: therese.nilsson@nek.lu.se.
} 


\section{Introduction}

Globalization is controversial: while some relate it to trade, freedom and growth, and regard these perceived outcomes as benefits, others believe globalization threatens domestic cultures, social cohesion and stable economies and take a negative position. ${ }^{1}$ A first step towards resolving contentious policy issues of this kind is to produce more research on the consequences of globalization. Indeed, a growing literature assesses its economic consequences, but knowledge is very limited on if and how globalization affects social attitudes. ${ }^{2}$ We believe we are the first to study whether globalization is related to an important social attitude - the willingness to teach children to be tolerant. ${ }^{3}$

Tolerance is arguably important in itself: it enables people to lead the lives they want without social and legal disapprobation, which brings about happiness (Inglehart et al., 2013). This is especially important for minorities of different kinds, who may be strongly affected by the attitudes of the surrounding majority in what they feel they can do and be (Corneo and

\footnotetext{
${ }^{1}$ To mention some books taking a stand on globalization, Bauman (1998) develops a skeptical perspective, Bhagwati (2004) stresses many of the economic and Cowen (2002) many of the cultural benefits, Stiglitz (2003) and Rodrik (2007) acknowledge the socioeconomic progress that globalization has brought about while also stressing some of its main problems. See Guillén (2001) and Fischer (2003) for outlines of the wider globalization debate.

${ }^{2}$ Like us, many recent studies make use of a relatively new measure of globalization, the KOF Index (for an overview see Potrafke, 2013). Some of the studies using this index relate globalization to economic growth (Dreher, 2006a; Bergh and Karlsson, 2009), to the size of the welfare state (Dreher, 2006b; Meinhard and Potrafke, 2012), to the willingness to help others (Koster, 2007), to human well-being and life satisfaction (Tsai, 2007; Bjørnskov et al., 2008; Hessami, 2011), to the composition of public expenditures (Dreher et al., 2008), to inequality (Dreher and Gaston, 2008; Bergh and Nilsson, 2010a), to life expectancy (Bergh and Nilsson, 2010b), to the protection of human rights (de Soysa and Vadlamannati, 2011; Dreher et al., 2012), to ethnocentricity (Machida, 2012) and to gender equality (Potrafke and Ursprung, 2012). For an overview of research on the consequences of globalization using other measures than the KOF index, see, e.g., O’Loughlin et al. (2004). Lastly, somewhat in line with the thesis of this study, Inglehart and Abramson (1999) and Inglehart (2000) associate globalization with the spread of postmaterialist values stressing freedom, self-expression and the quality of life.

${ }^{3}$ We define "globalization" as social, economic and political processes that tend towards integrating people, organizations and nations of the world through lower physical or mental transaction costs. This is in line with Guillén’s (2001: 236) definition of globalization as “a process leading to greater interdependence and mutual awareness (reflexivity) among economic, political, and social units in the world, and among actors in general”. We follow Corneo and Jeanne (2009: 691) in defining "tolerance" as “respect for diversity", and Florida (2003: 10), who defines it as "openness, inclusiveness, and diversity to all ethnicities, races, and walks of life".
} 
Jeanne, 2009). But tolerance is also related to economic outcomes. Mokyr (1990: 12) has studied economic development in a historical perspective and finds that "innovation requires diversity and tolerance”. Florida (2003: 11) explains the logic:

Places that are open and possess low entry barriers for people gain creativity advantage from their ability to attract people from a wide range of backgrounds. All else equal, more open and diverse places are likely to attract greater numbers of talented and creative people - the sort of people who power innovation and growth.

There is moreover empirical evidence for an association between tolerance, on the one hand, and income and economic growth, on the other. ${ }^{4}$

If globalization is able to foster tolerance, this means that widely embraced social and economic goals can be better achieved by opening up borders, which is a reason for taking a positive view of globalization. Such a finding would also improve our knowledge of the mechanisms at work behind the positive relationship between globalization and economic growth, as tolerance then would be a mediator.

Why would globalization relate to a willingness to create tolerant societies? We propose two grounds for such an expectation. First, globalization could influence the values of adults such that they internalize a positive outlook on others who are different. This could come about in different ways, through cultural influences and through economic interaction, where people come to realize that others who are different can be decent and honest. ${ }^{5}$ This in effect means that globalization could instill a taste for tolerance in adults. And if they think that their own preferences are desirable for the new generation, they may consequently, in an "imperialistic" fashion, consider it important for their offspring to be tolerant as well. Second, globalization implies that children likely become more successful in life if they interact freely with others irrespective of characteristics such as gender, ethnicity, nationality, sexual

\footnotetext{
${ }^{4}$ See, e.g., Florida (2002), Ottaviani and Peri (2006), McGranahan and Wojan (2007), Das et al. (2008), Florida et al. (2008) and Berggren and Elinder (2012). Cf. Tabellini (2010).

${ }^{5}$ Relating to cultural influences, there are studies that document an international transmission of norms, e.g., with regard to inequality (Atkinson, 1997), corruption (Sandholtz and Gray, 2003), obesity (Mendez and Popkin, 2004), education (Huisman and Smits, 2009) and the use of child labor (Congdon Fors, 2012). Other studies find that television affects values and behavior (e.g., Gentzkow and Shapiro, 2004; DellaVigna and Kaplan, 2007; Jensen and Oster, 2009). Relating to economic interaction, Berggren and Jordahl (2006) show that marketoriented institutions and policies seem to be able to stimulate social trust, and Berggren and Nilsson (2012) document a similar effect for tolerance towards homosexuals.
} 
orientation and religion. In a world that is increasingly integrated - economically, socially and politically - tolerance is arguably an important asset for the new generation to have. In meeting people who are different from themselves, both in their home countries and when travelling, studying or working abroad, today's children will then be better equipped to adapt and make use of their productive talents. Adults who realize this could wish their offspring to be tolerant (irrespective of whether the adults are tolerant themselves), on altruistic grounds. Both of the above described mechanisms could be at work and establish a link between globalization and a widespread view that it is important to teach kids tolerance.

We provide an empirical study of whether there is such a link. Our dependent variable is the share in different countries that replies that it is important to teach kids tolerance (as reported by the World Values Survey and the European Values Study). Taking a multidimensional perspective, our main explanatory variables of interest, from the KOF Index of Globalization, are economic, social and political globalization and their sub-components. Adding various control variables used in previous studies on tolerance, and performing both cross-sectional and panel-data analyses encompassing up to 66 countries, we indeed find that globalization enhances the willingness to transmit tolerance to children. More precisely, in our cross-sectional analysis, we find that economic and social, but not political, globalization correlate with our tolerance variable. The economic factor of most importance is trade flows, whereas the social factors of relevance are personal contacts and cultural proximity. The panel-data analysis, with country- and time-fixed effects, largely confirms baseline findings. The panel-data results suggest that social globalization is the most important dimension of globalization for the transmission of tolerance, and in particular the sub-component cultural proximity. But in the area of economic globalization, the factor (absence of) trade restrictions is also positively related to our dependent variable. Using an instrumental-variable approach further suggests the relationship between globalization and the willingness to transmit tolerance to children to be causal. Lastly, we find some indications of altruism (rather than imperialism) being the more important basis, on average, for parents' willingness to teach children tolerance: They seem to wish to do so because they think a tolerant outlook will benefit their offspring in the future (not necessarily because they themselves are tolerant). In all, our findings seem to confirm that certain dimensions of the globalization process shape social values about how to bring up children, in ways considered desirable by many. 
Our study can be placed not only among studies of the effects of globalization, several of which were cited above, but also among studies of the determinants of tolerance. ${ }^{6}$ This literature, as well as our study, belongs to an emerging field in economics where cultural and social factors, such as tolerance, religiosity and social trust, are studied, both as determinants and consequences of economic variables. ${ }^{7}$ This study also relates to a literature on the transmission of values to children. For our dependent variable, which conveys the attitude that it is important to teach tolerance, to be relevant it is required that adults are actually able to transmit values to children, at least to some extent. Reassuringly, there are indications of this, e.g., when it comes to conservatism (Vollebergh et al., 1999), female labor force participation (Fernández et al., 2004), work ethic (Bogt et al., 2005), certain aspects of religiosity (Koenig et al., 2005; Bradshaw and Ellison, 2008), party choice (Hatemi et al., 2008; Settle et al., 2009), attitudes towards euthanasia, homosexuality and ethnic minorities (Jaspers, 2008), generosity (Wilhelm at al., 2008), cognitive and non-cognitive skills (Coneus and Sprietsma, 2009; Coneus et al., 2012), trust (Butler et al., 2012; Dahmen et al., 2012; Ljunge, 2012; Zumbuehl et al., 2013) and risk attitudes (Dahmen et al., 2012; Zumbuehl et al., 2013). Parent-child attitudes are by no means perfectly correlated, but neither are they uncorrelated. ${ }^{8}$ It bears noting, however, that even if the effect of attempts to teach kids tolerance was de facto non-existent, parents could still, if they did not know that such attempts were futile, consider it important to teach kids tolerance.

The rest of the paper is structured as follows. After a presentation of our theoretical approach in Section 2, Section 3 describes the data and the empirical strategy. Section 4 reports and discusses the empirical results, after which we offer concluding remarks.

\footnotetext{
${ }^{6}$ Among previous factors found to be relevant for tolerance, the following bears mentioning: free trade (Spitz, 2004), inequality (Andersen and Fetner, 2008), GDP per capita and becoming a new member state of the European Union (Corneo and Jeanne, 2009) and monetary stability and the rule of law (Berggren and Nilsson, 2012). Note, however, that our dependent variable is not tolerance as such but the share of people that holds the view that tolerance should be taught to kids. The latter arguably affects but does not totally determine the former. ${ }^{7}$ See, e.g., Tabellini (2008a, 2010), Guiso et al. (2009), Berggren and Bjørnskov (2011) and, for a survey, Férnandez (2011).

${ }^{8}$ For a comprehensive survey documenting how parents transmit traits through socialization, see Bisin and Verdier (2011). This is not to deny that there are genetic influences as well: see, e.g., Cesarini et al. (2009).
} 


\section{Theoretical Expectations}

In this Section, we present theoretical reasoning about why and how globalization (in its different forms) is expected to affect the attitudes of adults with respect to teaching kids tolerance. ${ }^{9}$ Our theory does not imply that a willingness to teach kids tolerance is either sufficient or necessary for tolerance to appear, but the assumption is that such willingness is related to attempts to actually teach tolerance and to tolerance as such later on.

\subsection{Two Basic Grounds for a Relationship}

Why might adults think it important to teach children tolerance? We propose two bases for such an attitude: one "imperialistic" - which stems from a desire to impose on children the kind of value system which the adults themselves value - and one "altruistic" - which stems from a desire to help children do as well as possible. ${ }^{10}$ In the imperialistic case, parents have certain preferences and want the children to adopt traits and make choices that satisfy the parents' preferences, irrespective of whether this raises or lowers the utility of the children. If the parents value tolerance or intolerance, they think the children should do so as well, period. This social attitude could, e.g., build on a concern for community and union in the family; or it could be the result of an automatic, unreflected and a-consequentialist way of thinking.

In the altruistic case, parents want their children to be as well off as possible and hence experience increased utility if their children do so. This is a consequentialist outlook, where parents will do their best to encourage their children to adopt traits and make choices that maximize their children's utility. If parents believe that a tolerant outlook brings with it greater chances for good outcomes in life, then they will try to teach their children tolerance (but again, if they think that the children will benefit from intolerance, they will try to make the children intolerant). ${ }^{11}$

\footnotetext{
${ }^{9}$ Although we primarily talk about parents here, since these are more directly concerned about (their) children than others and also in a better position to influence (their) children than others, the attitudes of adults that we discuss could also be present in non-parents that care about children (in the extended family or in other social settings, such as schools and voluntary organizations). Cf. Christopoulou et al. (2013).

${ }^{10}$ Doepke and Zilibotti (2012) model the intergenerational transmission of patience and risk attitudes for different parental types, somewhat akin to our distinction here.

${ }^{11}$ Note that these considerations of parents need not correspond to reality ex post: It could, e.g., be that the values that imperialistic parents (try to) instill are more conducive to the child's future de facto well-being than
} 
The imperialistic basis may be seen as akin to the modeling of parents by Bisin and Verdier (2000, 2001), Bisin et al. (2004) and Tabellini (2008b); the altruistic basis follows the modeling of parents by Corneo and Jeanne (2009). We posit that parents in general are both imperialistic and altruistic, to varying degrees.

\subsection{A Positive Effect of Globalization}

What interests us here is how globalization might affect parents' willingness to transmit tolerance to their offspring. More specifically, we distinguish between three dimensions of globalization: economic, social and political. The mechanisms at work differ for the three types, but also for the imperialistic and altruistic bases for wanting to socialize one's children. We therefore discuss these cases in turn and explain why we expect globalization to affect parents to want to teach kids tolerance.

Economic globalization entails both actual economic activities (such as trade, capital flows and investments), and the institutions and policies that regulate the actual activities: the more of the activities and the more liberal the regulations, the more globalization there is. ${ }^{12}$ First, there is reason to expect an internalization effect in favor of tolerance for parents with an imperialistic motive. Internalization is a process of developing a way of reacting and thinking that produces a spontaneous and unreflected tendency to assess, in our case, people that are different in a generous way. We primarily expect the economic activities to affect parents' tolerance and hence the teaching of their kids to be tolerant. The mechanism is that a practice of commercial interaction and trade induces people to understand others and to not see them as threatening. In a society that increasingly experiences this, more tolerance could be the result. ${ }^{13}$ Second, both imperialistic and altruistic parents also look out, in a conscious

the values that altruistic parents (try to) instill. This is because future outcomes of this kind are not only the result of the motivation of parents but also of their (imperfect) ability to know what the future entails, in terms of how their attempts to influence children work in practice and in terms of what kind of objective reality children will encounter.

${ }^{12}$ If institutions and policies have an effect on tolerance it is probably of an indirect nature: by affecting the economic activities that can take place. If the institutions and policies cover economic activities that are not measured directly, there could hence be an effect.

${ }^{13}$ This is akin to Montesquieu's doux commerce thesis. Cf. Henrich et al. (2001), who find experimental evidence for market integration explaining much of behavioral variations across societies. The idea is that the more people engage in market transactions, the more they will experience abstract sharing principles concerning behaviors toward strangers. 
way, for what is in their or their children's best interest. As economic opportunities across borders manifest themselves, parents may realize that they and their children benefit from interaction and exchange with numerous others, at home and abroad (cf. Bowles, 1998: 100 ff). By being intolerant, by not being open to and not letting in people that are different from oneself into one's life or into society, one foregoes a chance for enrichment. Intolerance comes at a cost, which will tend to discourage it. ${ }^{14}$ Hence, in a setting with increasing globalization, competing, profit-seeking firms and people set on maximizing well-being, there will be a stronger incentive to be tolerant and to try to make children tolerant. ${ }^{15}$

Social globalization entails personal contacts in general, information flows and cultural proximity. With more social globalization parents will absorb novel impressions, be subjected to values and access information from many new sources to a higher degree, as this type of "cultural” interaction grows stronger, both through media, the Internet, traveling, migration and the presence of foreign companies of various kinds. Meetings and experiences, not least of other forms of life, can encourage tolerance directly, if people learn to appreciate the contributions made by those who are different. Furthermore, to the extent that the ideas and influences that dominate are broadly liberal in character, as suggested by, e.g., Inglehart and Abramson (1999), Inglehart (2000), Sklair (2001) and Rosenau (2003), a tolerant outlook plausibly becomes stronger for that reason as well. ${ }^{16}$ As in the case of economic globalization,

\footnotetext{
${ }^{14}$ This relates to the theory of discrimination introduced by Becker (1971), who points at a mechanism in markets for reducing the exclusion from the economy of people on other bases than low productivity. For example, firms who do not hire people of a certain race or who do not purchase intermediate products from firms abroad, even though they are more productive, are at a disadvantage in the process of competition and experience lower profits than they otherwise would have. Globalization increases competitive pressures, which will tend to discourage discrimination. Indeed, Black and Brainerd (2004) find empirical support for globalization reducing gender discrimination in manufacturing industries.

${ }^{15}$ A possible indirect effect of globalization on the willingness to teach kids tolerance is more education. With globalization labor markets become increasingly international and returns to education tend to increase, which gives incentives for human-capital accumulation. This can lead to more educated parents, who through their education have become more tolerant (through teaching and social interaction with others, possibly also with students from other backgrounds). Imperialistic parents will then try to teach their children to be tolerant. Altruistic parents will realize that education is an increasingly valuable asset - partly because this generally makes people more tolerant - making them more inclined to encourage their children to get educated. Cf. Heineck and Riphahn (2007), Jaspers (2008: 29), Jensen and Oster (2009: 1060) and Congdon Fors (2012: 7). ${ }^{16}$ For example, the power of television in affecting social norms is demonstrated by Jensen and Oster (2009) in the case of the status of women in India, by Chong and La Ferrara (2009) in the case of divorce in Brazil and by La Ferrara et al. (2012) in the case of fertility in Brazil.
} 
the influence could come both through internalization (for imperialistic parents) and through a realization that it is better to adapt to a situation where one can benefit from interaction with others (for both imperialistic and altruistic parents).

Political globalization entails things on the national level, such as political exchange through foreign representation, membership in international organizations, participation in international missions and the adoption of international treaties. Since this type of globalization can primarily be expected to have an effect on parents who participate personally, and since such parents are few in any country, we expect the effect here on tolerance to be weaker. Still, there could perhaps also be an effect from the citizens of a country having a feeling that their country is part of an international political community. Both through internalization (as it then feels more natural to sympathize with people of different backgrounds) and through self-interest considerations (due to the many international political ties and exchanges, one and one's children might benefit from an open attitudes towards others) there could be a positive effect. ${ }^{17}$

To summarize our theoretical expectations, parents acting imperialistically towards their children become more tolerant through economic, social and political globalization because of an internalization effect and because of their self-interest. They will wish for their children to be more tolerant, as they want them to have the same traits and dispositions as themselves, and will therefore consider it important to teach the kids tolerance. Parents acting altruistically only care for what is in the children's best interest, and they will realize that children will be better equipped to flourish when economic, social and political globalization increases if they are tolerant and open to all kinds of people, with different nationalities, ethnicities, gender, sexual orientation, religion etc. Lastly, let us stress that we are not saying that globalization will necessarily bring about high absolute tolerance levels, only that more globalization can be expected to generate more tolerance (or less intolerance).

\subsection{A Negative Effect of Globalization}

\footnotetext{
${ }^{17}$ Even if the direct relationship between political globalization and tolerance isn't strong, political integration may however have indirect effects on social attitudes. The political economy literature suggest political globalization relates to economic globalization (de Haan et al 2006) and closer political relationships may spur and promote trade between countries. Increasing political relationships with other countries can also translate to shared preferences for social attitudes such as tolerance on paper (e.g. countries signing the UN declaration on human rights) and in action.
} 
Although our main hypothesis is that the relationship between globalization and willingness to teach tolerance is positive, globalization might also contain elements that reduce tolerance and a willingness to teach it to kids. The two main reasons for expecting a negative effect, we suggest, are cultural exclusivism and fear (and the two may very well be related in practice). By the former, we mean that people think it increasingly important to resist what they perceive to be the erosion of traditional (local or national) cultures; by the latter we mean that as globalization by definition entails economic, social and political change, this makes life less certain (Scheve and Slaughter, 2004), which can make people worry and resist this process. People and ideas that are different might consequently be regarded as threats: they should not be let into “our” world. ${ }^{18}$ As suggested by Arnett (2002), people can develop oppositional identities that reinforce a "we-against-the-outsiders" kind of thinking, where the own group should be strengthened and be kept intact. ${ }^{19}$ Parents affected by this outlook can become less tolerant as a result of globalization, and they can be unwilling to teach their kids tolerance towards different people and ideas and rather transmit attitudes of intolerance. ${ }^{20}$

If we look at the three types of globalization separately, we expect economic globalization to be central if there is a negative effect, by increasing (perceived) uncertainty about such matters as unemployment and decision-making over companies, which could make parents less interested in teaching tolerance. Instead, they could increasingly start stressing the value of local production and ownership and problematize a foreign economic presence. Social globalization could result in a negative reaction by those who wish to preserve cultures as they are. For example, television programs portraying female empowerment could be disliked in male-dominated cultures, and a resulting dislike of those

\footnotetext{
${ }^{18}$ Holton (2000) talks about "polarization" to denote how globalization may create resistance and tensions with regard to new cultural influences. This can also be related to Putnam's (2000) notions of bridging and bonding social capital, where the former refers to bonds of connectedness that are formed across diverse social groups and where the latter refers to such bonds that only exist within homogenous groups.

${ }^{19}$ On oppositional identities, see Battu and Zenou (2010); cf. the notion of particularistic identities (Guillén, 2001: 253). On the economics of identity more generally, see Akerlof and Kranton (2000).

${ }^{20}$ However, while globalization may cause some people, who feel uneasy in a cosmopolitan world where new influences increasingly dominate, to develop a stronger identity based on local culture, this does not necessarily (or even plausibly) imply that they also become intolerant. It is perfectly possible to combine a preference for a strong local culture, and an identity based on it, with a tolerant attitude towards others: in fact, by having the comfort of the local culture, it may be easier for some people to respect others. One may realize that one can keep elements of the traditional social structure while respecting others: one does not have to adopt the practices of others just because one interacts with them.
} 
that transmit such values could result in reduced tolerance and a reduced willingness to teach tolerance. Among the three types of globalization, political globalization is once again the least easy to connect to possible tolerance effects. An increase in the foreign presence and involvement of one's own country may annoy isolationists, but most likely it will not affect the willingness to teach kids tolerance.

By recognizing that there could as well be negative effects of globalization on tolerance and the willingness to teach children tolerance, it becomes important to settle empirically whether positive or negative effects dominate and to see whether effects differ for different dimensions of globalization.

\section{Data and Empirical Strategy}

\subsection{Data}

To empirically investigate if globalization makes more parents willing to instill tolerance in their children, we use as our dependent variable the share of people in different countries who answer "Tolerance" when being asked the question: "Here is a list of qualities that children can be encouraged to learn at home. Which, if any, do you consider to be especially important?”, in the World Values Survey and European Values Study.

To measure globalization, we use the KOF Index of Globalization (Dreher, 2006a; Dreher et al., 2008). Its multidimensional character is one of the advantages with the index; another is that it covers a long time period, 1970-2012, and many countries. ${ }^{21}$ Our main explanatory variables are Economic, Social and Political globalization. We also take advantage of the possibility of further decomposing our globalization measures into their subcomponents - Trade flows and Trade restrictions (for Economic globalization), and Information flows, Personal contact and Cultural proximity (for Social globalization) - to better understand what specific components that matter. ${ }^{22}$ Box A1 in the Appendix describes the KOF Index of Globalization in detail.

\footnotetext{
${ }^{21}$ For example, while the KOF Index covers 122 countries, the Foreign Policy Index (A. T. Kearney/Foreign Policy Magazine, 2003) only covers 72 countries, while the CSGR index (Lockwood and Redoano, 2005) covers 106 countries, but only from 1982 until 2004.

${ }^{22}$ A similar decomposition for political globalization is not possible since there are no separate data for lower levels of this index.
} 
In addition, we make use of a number of potentially relevant control variables: Real GDP per capita, Education, Young population share, Urban population share, Family values, Religious fractionalization, Ethnic fractionalization, Religion Catholic, Religion Muslim, Net income Gini, Civil liberties, Political rights and a set of geographical dummies.

The choice of control variables is based on results in previous studies examining the determinants of tolerance, as well as on theoretical considerations. Material well-being and little competition over scare resources are likely to create more tolerance toward people different than oneself (Friedman, 2005; Andersen and Fettner, 2008). Education can be expected to increase tolerance through teaching and social interaction with others from other backgrounds. It is also perceivable that a society with a large share of young people, who are generally more open to new experiences than older people, is more tolerant. In a similar vein, the share of people living in urban areas likely relates to tolerance in a positive manner, since diversity is generally greater in urban than in rural areas.

Family value refers to the closeness of family ties (Alesina and Giuliano, 2010), and is the average of three variables: parents' duties and responsibilities, how much children should respect the elderly and how important family is in life. We expect a higher family value to correspond to a lower value for the willingness to teach kids tolerance (Ermisch and Gambetta, 2010). One reason is that children might be taught to be tolerant only towards people similar to themselves in close-knit families. To account for a potential link between heterogeneity and tolerance, we include two measures of religious and ethnic fractionalization. The predicted net effect on tolerance is unclear: while they may bring about an increase due to a greater probability of people meeting and getting to know others who are different, they may also bring about a decrease in tolerance, to the extent that differing groups tend to come into conflict with each other. The two religion variables capture shares of people who belong to a hierarchical religion, and it could be that identification with such a religion tends to decrease tolerance of those who do not follow the dictates of the prelates (Klosko, 2000; Bjørnskov, 2007). The two measures of political and civil rights control for aspects of freedom. The ability to participate freely in open debates and in how one's country is governed reasonably increases tolerance, but in some cases, one could envisage a negative effect, if increased political and civil freedom exposes inter-group conflicts. Lastly, the geographical dummies serve to control for effects that may be typical of certain regions without being captured by the other control variables (in our cross-section analysis).

For the cross-country dataset we use information on the importance of teaching kids tolerance from the last non-missing value in the two latest versions of the World Values 
Survey and European Values Study, i.e., in 2005 or 2000. Globalization and control variables in baseline regressions are collected for 1995. For the instrumental-variable analysis we use information on globalization in neighboring countries in 1985 and data on voting in the UN General Assembly in 1995. Descriptive statistics, definitions and sources of the variables are given in Table A1 in the Appendix. Table A2 in the Appendix provides a list of countries included in the analysis.

\subsection{Empirical Strategy}

We examine whether globalization affects the willingness to transmit tolerance to children using two main approaches. First, we carry out a cross-sectional analysis with regressions of the following form:

Importance teaching tolerance $_{i}=\alpha+\beta\left(\right.$ Globalization $\left._{d i}\right)+\gamma\left(X_{i}\right)+\varepsilon_{i}$

Globalization $_{d i}$ denotes the KOF Index of Globalization of dimension $d$ for country $i$, and $\mathrm{X}_{i}$ is a vector of control variables for country $i$, including the regional dummies. As described above the explanatory variables predate the dependent variable. A lagged specification is reasonable since it reduces the risk that tolerance influence globalization and since the potential globalization effect plausibly works with a delay - it is first when one can see and when one has had time to encounter the effects of globalization that one's willingness to transmit tolerance to children can reasonably be affected.

A cross-sectional analysis is useful as it gives a first indication on the lon-run “equilibrium” relationship between types of globalization and the importance of teaching kids tolerance, but several caveats apply. First, presuming reverse causality between globalization and the view on the importance of teaching kids tolerance, we test for causality using an instrumental variable approach. Second, if there are factors that are excluded from the analysis that affect the view of the importance of teaching tolerance but also globalization, the noted cross-sectional associations will capture the existence of omitted variables rather than a true globalization-effect. Our second approach is therefore to conduct a panel-data analysis running regressions of the form:

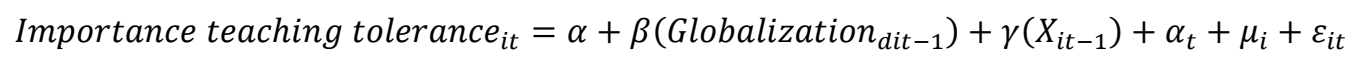


Globalization $_{\text {dit-1 }}$ and $\mathrm{X}_{\text {it-1 }}$ are defined as for formula (1), where the added t denotes the time period. $\alpha_{t}$ is a period-specific effect capturing the influence of "shocks" on tolerance in multiple countries at the same time, $\mu_{i}$ is a country fixed effect capturing stable differences between countries with respect to tolerance and the willingness to teach kids these values, and $\varepsilon_{i t}$ is a random noise error term. Following the above line of reasoning the explanatory variables and the control variables always predate the measure on the importance of teaching kids tolerance also in the panel setting. The panel is unbalanced with two or three observations for each country and includes values between 1980 and 2005 (with tolerance values starting in 1990). Consequently, the panel covers a rather short time period, and cultural values and social attitudes are often quite stable in the short run. However, these estimations are still of interest since they can be interpreted as capturing transitory effects.

\section{Results}

We begin our presentation of our results by showing simple scatter plots. We proceed by presenting cross-sectional and panel-data regression results. We then report findings from some robustness tests, an instrumental-variable analysis (in order to try to ascertain causality) and an attempt to ascertain whether parents, to the extent they are willing to teach kids tolerance, are primarily motivated by altruistic or imperialistic concerns.

\subsection{Plots}

Figure 1 plots the three dimensions of globalization against our measure of tolerance. From this exercise two things become evident. First, the bivariate correlation is strongest between economic and social globalization, respectively, and the tolerance measure, while political globalization does not seem strongly related to it. Second, the scatter plots indicate a couple of possible outlier observations, which calls for careful outlier testing. 
Figure 1 Dimensions of globalization and tolerance
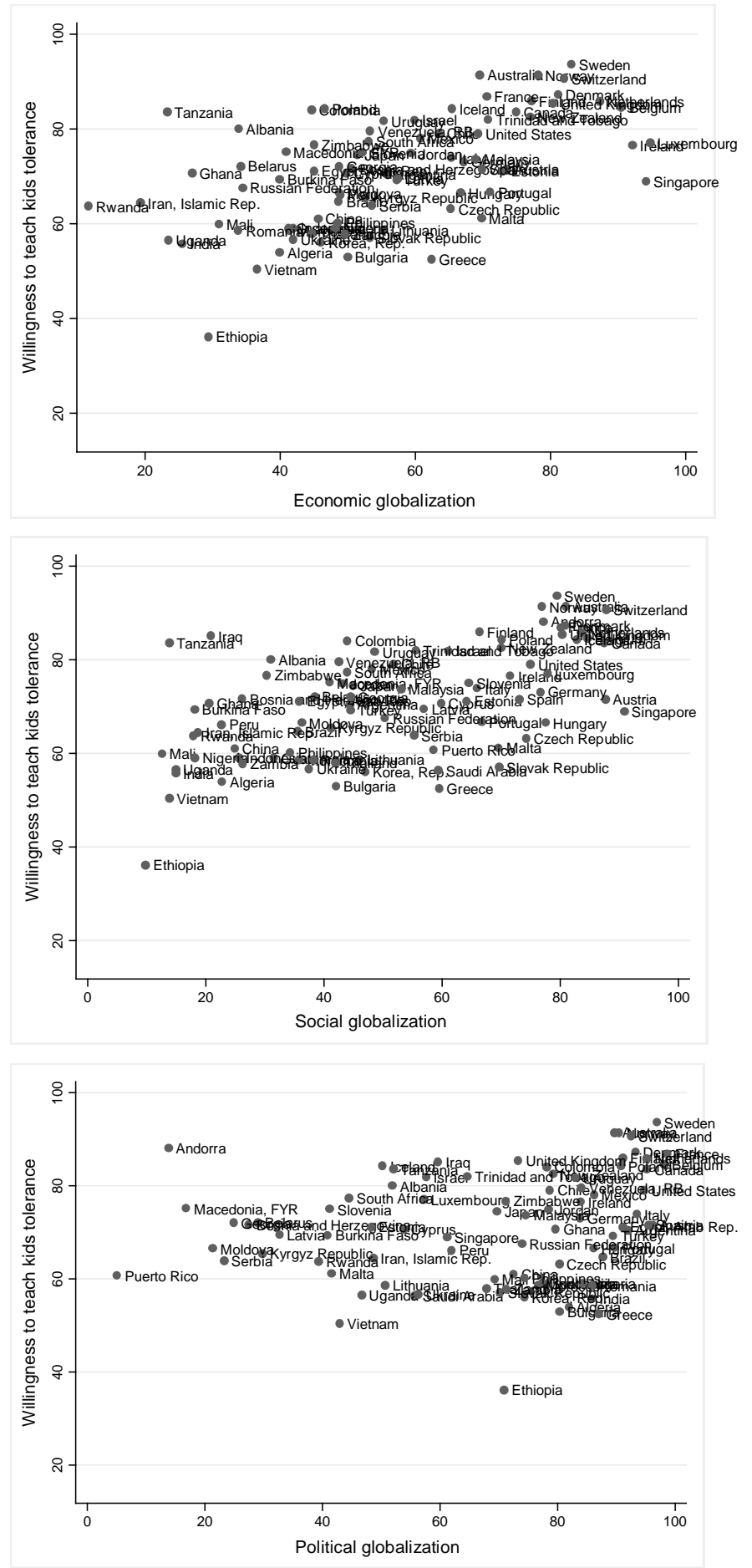

These bivariate correlations do, however, not take into account income levels and other potentially important determinants of the willingness to teach tolerance. To learn more about the validity and character of the different relationships, we move on to regression analysis. 


\subsection{Cross-Sectional Results}

Table 1 contains the results for the aggregate globalization index and the willingness to teach children tolerance. In line with our theoretical predictions, Globalization correlates positively with the willingness to teach kids tolerance. Gradually expanding the model and including more control variables reduces the magnitude of the estimated relationship somewhat, but results remain significant at conventional levels. Regarding the size of the effect, an increase in Globalization of 10 units (out of 100) - which approximately corresponds to the difference between the UK and the US - relates to an increase in the share of people who consider it important to teach kids tolerance by about 5 percentage points. We consider this a sizeable effect, given the observed variation in Globalization (see Table A1 in the Appendix). 
Table 1 Aggregate globalization and tolerance: cross-sectional results

\begin{tabular}{|c|c|c|c|c|}
\hline & (1) & (2) & (3) & (4) \\
\hline Globalization & $\begin{array}{c}0.561^{* * *} \\
{[0.082]}\end{array}$ & $\begin{array}{c}0.529 * * * \\
{[0.140]}\end{array}$ & $\begin{array}{c}0.495^{* * *} \\
{[0.143]}\end{array}$ & $\begin{array}{l}0.437 * * \\
{[0.184]}\end{array}$ \\
\hline Real GDP per capita & & $\begin{array}{c}0.638 \\
{[2.100]}\end{array}$ & $\begin{array}{c}1.060 \\
{[2.608]}\end{array}$ & $\begin{array}{c}0.392 \\
{[2.809]}\end{array}$ \\
\hline Education & & $\begin{array}{c}-0.010 \\
{[0.111]}\end{array}$ & $\begin{array}{c}0.004 \\
{[0.130]}\end{array}$ & $\begin{array}{c}-0.065 \\
{[0.137]}\end{array}$ \\
\hline Young population & & & $\begin{array}{c}0.024 \\
{[0.136]}\end{array}$ & $\begin{array}{c}0.158 \\
{[0.159]}\end{array}$ \\
\hline Urban population & & & $\begin{array}{c}0.033 \\
{[0.078]}\end{array}$ & $\begin{array}{c}0.043 \\
{[0.061]}\end{array}$ \\
\hline Family values & & & $\begin{array}{c}0.098 \\
{[0.176]}\end{array}$ & $\begin{array}{c}0.172 \\
{[0.144]}\end{array}$ \\
\hline Religious fractionalization & & & & $\begin{array}{c}3.930 \\
{[6.283]}\end{array}$ \\
\hline Ethnic fractionalization & & & & $\begin{array}{c}-5.380 \\
{[5.272]}\end{array}$ \\
\hline Religion - Catholic & & & & $\begin{array}{c}-0.058 \\
{[0.043]}\end{array}$ \\
\hline Religion - Muslim & & & & $\begin{array}{c}0.009 \\
{[0.072]}\end{array}$ \\
\hline Net income Gini & & & & $\begin{array}{c}-0.152 \\
{[0.220]}\end{array}$ \\
\hline Civil liberities & & & & $\begin{array}{l}-4.638^{*} \\
{[2.714]}\end{array}$ \\
\hline Political rights & & & & $\begin{array}{c}2.391 \\
{[2.039]}\end{array}$ \\
\hline East Asia & $\begin{array}{l}-1.203 \\
{[3.769]}\end{array}$ & $\begin{array}{l}-1.528 \\
{[3.885]}\end{array}$ & $\begin{array}{c}-0.531 \\
{[4.511]}\end{array}$ & $\begin{array}{c}1.537 \\
{[5.555]}\end{array}$ \\
\hline Europe & $\begin{array}{c}-1.559 \\
{[3.781]}\end{array}$ & $\begin{array}{l}-1.786 \\
{[4.167]}\end{array}$ & $\begin{array}{c}0.209 \\
{[5.078]}\end{array}$ & $\begin{array}{c}2.897 \\
{[4.633]}\end{array}$ \\
\hline Latin America & $\begin{array}{c}5.646 \\
{[3.669]}\end{array}$ & $\begin{array}{c}5.289 \\
{[3.956]}\end{array}$ & $\begin{array}{c}5.345 \\
{[4.234]}\end{array}$ & $\begin{array}{l}10.124 \\
{[6.695]}\end{array}$ \\
\hline North America & $\begin{array}{l}-0.403 \\
{[3.959]}\end{array}$ & $\begin{array}{l}-0.712 \\
{[4.476]}\end{array}$ & $\begin{array}{c}0.124 \\
{[4.910]}\end{array}$ & $\begin{array}{c}0.500 \\
{[6.479]}\end{array}$ \\
\hline South Asia & $\begin{array}{l}-1.007 \\
{[3.293]}\end{array}$ & $\begin{array}{l}-1.142 \\
{[3.938]}\end{array}$ & $\begin{array}{c}0.757 \\
{[5.147]}\end{array}$ & $\begin{array}{c}-3.825 \\
{[6.529]}\end{array}$ \\
\hline Sub-Saharan Africa & $\begin{array}{c}11.695 * * \\
{[5.261]}\end{array}$ & $\begin{array}{c}12.042 * * \\
{[5.393]}\end{array}$ & $\begin{array}{c}12.890^{* *} \\
{[5.379]}\end{array}$ & $\begin{array}{c}9.708 \\
{[10.376]}\end{array}$ \\
\hline Constant & $\begin{array}{c}35.959 * * * \\
{[5.198]}\end{array}$ & $\begin{array}{c}32.603^{* * *} \\
{[12.213]}\end{array}$ & $\begin{array}{c}18.044 \\
{[28.340]}\end{array}$ & $\begin{array}{c}29.632 \\
{[29.344]}\end{array}$ \\
\hline$\overline{\text { Adj. } R^{2}}$ & 0.467 & 0.449 & 0.423 & 0.457 \\
\hline Observations & 66 & 66 & 66 & 66 \\
\hline
\end{tabular}

In order to make more precise what elements of Globalization that drive these results, we use the same model to estimate the relationship between Economic, Social and Political globalization, on the one hand, and our tolerance measure, on the other. Results in Table 2 suggest that Economic and Social, but not Political, globalization is of particular importance for transmitting our social value. As for the control variables, they generally have the expected sign but are mostly not statistically significant. However, there seems to be a negative relationship between Civil rights and Ethnic fractionalization, respectively, and the willingness to instill tolerance in children, while Family value, contrary to expectations, correlates positively with the dependent variable in the case of economic globalization. 
Moreover higher GDP per capita associates with a higher willingness to teach kids tolerance in the case of political globalization.

Table 2 Three dimensions of globalization and tolerance: cross-sectional results

\begin{tabular}{|c|c|c|c|c|c|c|c|c|c|}
\hline & (1) & (2) & (3) & (4) & (5) & (6) & (7) & (8) & (9) \\
\hline \multirow[t]{2}{*}{ Economic globalization } & $0.471^{* * *}$ & $0.319 * *$ & $0.295^{*}$ & & & & & & \\
\hline & {$[0.087]$} & {$[0.120]$} & [0.149] & & & & & & \\
\hline \multirow[t]{2}{*}{ Social globalization } & & & & $0.473^{* * *}$ & $0.426 * * *$ & $0.430 * *$ & & & \\
\hline & & & & {$[0.073]$} & {$[0.135]$} & [0.177] & & & \\
\hline \multirow[t]{2}{*}{ Political globalization } & & & & & & & $0.215^{* * *}$ & 0.015 & 0.015 \\
\hline & & & & & & & {$[0.066]$} & {$[0.077]$} & {$[0.083]$} \\
\hline \multirow[t]{2}{*}{ Real GDP per capita } & & 3.327 & 1.728 & & 1.415 & 0.189 & & $7.506 * * *$ & $5.480 *$ \\
\hline & & {$[2.337]$} & [2.455] & & {$[2.763]$} & [2.523] & & {$[2.456]$} & {$[2.884]$} \\
\hline \multirow[t]{2}{*}{ Education } & & -0.003 & -0.069 & & -0.007 & -0.043 & & -0.000 & -0.097 \\
\hline & & {$[0.136]$} & [0.138] & & [0.129] & {$[0.130]$} & & {$[0.140]$} & {$[0.148]$} \\
\hline \multirow[t]{2}{*}{ Young population } & & -0.006 & 0.137 & & 0.088 & 0.185 & & 0.104 & 0.236 \\
\hline & & [0.133] & {$[0.158]$} & & {$[0.140]$} & {$[0.168]$} & & {$[0.171]$} & {$[0.200]$} \\
\hline \multirow[t]{2}{*}{ Urban population } & & 0.057 & 0.065 & & 0.035 & 0.033 & & 0.099 & 0.091 \\
\hline & & {$[0.073]$} & {$[0.065]$} & & {$[0.074]$} & {$[0.066]$} & & {$[0.099]$} & {$[0.071]$} \\
\hline \multirow[t]{2}{*}{ Family values } & & 0.208 & $0.278^{*}$ & & 0.083 & 0.142 & & 0.198 & 0.245 \\
\hline & & {$[0.192]$} & [0.147] & & {$[0.176]$} & {$[0.142]$} & & {$[0.216]$} & {$[0.157]$} \\
\hline \multirow[t]{2}{*}{ Religious fractionalization } & & & 4.379 & & & -0.837 & & & 7.520 \\
\hline & & & [6.390] & & & {$[6.486]$} & & & {$[6.506]$} \\
\hline \multirow[t]{2}{*}{ Ethnic fractionalization } & & & $-10.611^{* *}$ & & & -8.053 & & & -8.049 \\
\hline & & & {$[5.271]$} & & & {$[5.006]$} & & & {$[7.244]$} \\
\hline \multirow[t]{2}{*}{ Religion - Catholic } & & & -0.044 & & & -0.064 & & & -0.043 \\
\hline & & & {$[0.042]$} & & & {$[0.041]$} & & & {$[0.046]$} \\
\hline \multirow[t]{2}{*}{ Religion - Muslim } & & & 0.022 & & & 0.019 & & & 0.015 \\
\hline & & & {$[0.070]$} & & & {$[0.069]$} & & & {$[0.079]$} \\
\hline \multirow[t]{2}{*}{ Net income Gini } & & & -0.210 & & & -0.129 & & & -0.057 \\
\hline & & & {$[0.235]$} & & & {$[0.220]$} & & & {$[0.250]$} \\
\hline \multirow[t]{2}{*}{ Civil liberities } & & & -4.229 & & & $-4.592 *$ & & & $-6.044 * *$ \\
\hline & & & {$[2.821]$} & & & [2.719] & & & {$[2.596]$} \\
\hline \multirow[t]{2}{*}{ Political rights } & & & 2.034 & & & 2.716 & & & 3.166 \\
\hline & & & {$[2.040]$} & & & {$[1.957]$} & & & {$[2.070]$} \\
\hline Adj. $R^{2}$ & 0.403 & 0.404 & 0.446 & 0.476 & 0.437 & 0.482 & 0.126 & 0.314 & 0.370 \\
\hline Observations & 66 & 66 & 66 & 66 & 66 & 66 & 66 & 66 & 66 \\
\hline
\end{tabular}

We also take advantage of the possibility to further decompose Economic and Social globalization. Table 3 presents the estimated coefficients of the five sub-components without reporting, for reasons of space, the findings for the control variables. Interestingly, the factor driving the relationship with Economic globalization is Trade flows. Larger volumes of trade consequently increase the willingness to teach kids tolerance. Moreover, the factors Personal contact and Cultural proximity drives the positive relationship between social globalization and willingness to transmit the social value tolerance. Personal contact primarily measures telephone traffic, tourism, the share of the population that is foreign and international letters 
per capita; Cultural proximity refers to the number of McDonald's restaurants per capita, the number of IKEA stores per capita and trade in books.

Table 3 Components of economic and social globalization and tolerance: cross-sectional results

\begin{tabular}{|c|c|c|c|c|c|c|c|}
\hline & $(1)$ & (2) & (3) & $(4)$ & $(5)$ & $(6)$ & $(7)$ \\
\hline \multirow[t]{2}{*}{ Trade flows } & $0.156^{*}$ & & 0.121 & & & & \\
\hline & {$[0.091]$} & & {$[0.089]$} & & & & \\
\hline \multirow[t]{2}{*}{ Trade restrictions } & & 0.258 & 0.209 & & & & \\
\hline & & [0.164] & {$[0.176]$} & & & & \\
\hline \multirow[t]{2}{*}{ Personal contact } & & & & $0.247 *$ & & & $0.223^{*}$ \\
\hline & & & & [0.124] & & & [0.128] \\
\hline \multirow[t]{2}{*}{ Information flows } & & & & & 0.184 & & 0.019 \\
\hline & & & & & [0.159] & & [0.154] \\
\hline \multirow[t]{2}{*}{ Cultural proximity } & & & & & & $0.164 * *$ & $0.151^{* *}$ \\
\hline & & & & & & {$[0.071]$} & [0.064] \\
\hline Adj. $R^{2}$ & 0.383 & 0.424 & & 0.439 & 0.394 & 0.434 & 0.471 \\
\hline Observations & 64 & 66 & & 66 & 66 & 66 & 66 \\
\hline \multicolumn{8}{|c|}{ Notes : Robust standard errors in parentheses } \\
\hline \multicolumn{8}{|c|}{$*$ significant at $10 \%,{ }^{* *}$ significant at $5 \%,{ }^{* * *}$ significant at $1 \%$} \\
\hline \multicolumn{8}{|c|}{ All estimated equations include a full set of control variables, a constant term and country-group dummie } \\
\hline \multicolumn{8}{|c|}{ Trade flows and Trade restrictions are components of Economics globalization, while Personal cont } \\
\hline
\end{tabular}

To check the robustness of our baseline findings we perform two sensitivity tests. First, we use least trimmed squares (LTS) to carry out a test of observations that deviate from the linear pattern followed by the majority of the data. ${ }^{23}$ In line with Rousseeuw and Leroy (1987), we proceed as follows. Using the cross-sectional sample, a regression line is calculated by using the $75 \%$ of the observations that minimize the sum of the squared residuals. The remaining $25 \%$ of the observations are then added, and residuals for all observations are computed. We regard countries with a standardized residual above 2.5 as outliers. After that, reweighted least squares is used for inference: outliers are given the weight zero and the rest the weight one. The main advantage of LTS is that it can handle cases with several jointly influential outliers. In our case, the method can handle cases where up to one fourth of the observations are jointly influential. Point estimates for the willingness to teach kids tolerance when outliers are removed suggest that our baseline results are not sensitive to outliers, as the size of the globalization estimates increase and statistical significance is retained throughout.

\footnotetext{
${ }^{23}$ For arguments in favor of using LTS, see Temple (1999) and and Sturm and de Haan (2005).
} 
Second, we change the model specification by excluding income inequality, as it could be a potential mediator in the relationship between globalization and tolerance (Berggren et al., 2008; Bergh and Nilsson, 2010a). A mediator is a factor that is influenced by globalization and in turn affects tolerance. It is not evident that a mediator should be included as a regressor, as it will reduce the estimated globalization effect. In line with the finding that income inequality is not significant in baseline regressions, the estimated Globalization coefficients remains of the same magnitude when excluding the Net income Gini coefficient, suggesting that inequality is not a mediating factor in the relationship between globalization and the willingness to teach kids tolerance.

\subsection{Instrumental-Variable Estimations}

The cross-sectional results seem to imply that economic and social globalization increases people's willingness to teach the next generation tolerance. However, it is not unreasonable to think that globalization is endogenous to such willingness. For example, the results might mirror reverse causality, since intolerance towards other cultures could deter foreign direct investments, trade and tourism (important indicators of globalization), in which case these types of globalization would be a result of rather than a cause of tolerance. ${ }^{24}$ For this reason we use an instrumental-variable (IV) approach, where we instrument our measures of globalization, in order to see if we can find indications of a causal effect from our tolerance measure to globalization. We use two instruments: the preceding average level of globalization in neighboring countries, as measured by the aggregate KOF index, and a voting-similarity index capturing how often a country's vote in the UN General Assembly coincides with the how the United States votes.

The use of the first instrument is based on the idea of "peer effects" of opening up country boarders and becoming more economically and socially integrated with the world economy. Such effects can be expected to be closely related, with some lag, to a country's own globalization level - but it is hard to see how the willingness to teach kids tolerance in a neighboring country can affect the globalization of the neighbors (especially as this globalization measure temporally precedes the tolerance measure). The idea behind this

\footnotetext{
${ }^{24}$ The risk of reverse causality is likely larger if parents are motivated by imperialism (see Section 2), since this motivation means that the parents themselves hold the values they try to instill in their children and since this is more readily related to attempts to affect policies and practices determining the scope of globalization (compared to parents being motivated on altruistic grounds).
} 
instrument has previously been applied. For example, Gassebner et al. (2011) find that economic reforms are affected by reforms adopted by other countries, and Eichengreen and Leblang (2008) and de Soysa and Vadlamannati (2011) both instrument variables of openness with the lagged values of openness of neighboring countries.

We define two countries as neighbors if they share a land or maritime boundary, the latter as recognized by the United Nations Convention on the Law of the Sea. For example, Latvia, Finland and Russia, but also Sweden, are defined as neighbors of Estonia. However, territories are not classified as neighboring countries. ${ }^{25}$ Globalization in neighboring countries is measured in 1985, i.e., ten years before the country-specific globalization value being instrumented.

As for our second instrument, trade dependence on powerful states or large economies such as the United States impacts partner countries' political alignments with these states in the United Nations (Richardson and Kegley, 1980; Armstrong, 1981). Voting similarity with the United States in the United Nations could therefore be expected to correlate with measures of globalization, and consequently UN voting-similarity indices have been used as an instrument by, e.g., Dreher and Sturm (2012) and Cho (2013). ${ }^{26}$ Furthermore, we are not aware of any empirical results showing a relationship between tolerance and patterns of UN voting, nor do we see any theoretical basis for expecting such a relationship to exist. The data comes from Strezhnev and Voeten (2013) and refer to voting similarity with the United States in the UN General Assembly in 1995. The index range between 0 and 1, where a higher value implies higher voting similarity between the countries considered. ${ }^{27}$

The chosen instruments should not vary systematically with the error term, i.e., not have an independent effect on the dependent variable other than through the instrumented variable corresponding to a country's own globalization. To test this assumption we first include the two instruments in our baseline specification. As shown by the results in columns 1-4 of Table 4, our instruments fulfill an important validity requirement, since they are more or less completely unrelated to the willingness to teach children tolerance. Importantly, they do not significantly associate with the dependent variable when controlling for the level of

\footnotetext{
${ }^{25}$ A complete list of neighboring countries is available from the authors on request.

${ }^{26}$ See Dreher et al. (2008b) on the different ways UN voting coincidence has been calculated in the literature.

${ }^{27}$ The voting-similarity index is calculated as the total number of votes where both states agree divided by the total number of joint votes and uses three category data $(1=$ "yes" or approval for an issue; 2 = abstain, $3=$ "no" or disapproval for an issue.) Abstention is therefore counted as half-agreement with a yes or no.
} 
globalization. Moreover, including the instruments in the baseline specification adds little explanatory value and does not change the baseline coefficients on globalization very much.

Second, instrument relevance requires that instruments should be correlated with our measures of globalization. Columns 5-7 of Table 4 show results from the first-stage regressions estimating the relationship between, on one hand, the neighbors' average globalization and voting similarity with the United States in the United Nations, and measures of globalization, including a full set of control variables and region dummies, on the other hand. P-values of first-stage F-tests indicate that the instruments are jointly significant in all three specifications, suggesting they are quite powerful in predicting globalization.

Finally, columns 8-10 of Table 4 presents the second-stage regression results, where predicted globalization levels are used to estimate the effect on the willingness to teach children tolerance. ${ }^{28}$ The exogenous parts of globalization remain significantly and positively related to our dependent variable. Our baseline finding that economic and social globalization increases the transmission of social values is moreover strengthened (magnitude-wise), suggesting that our initial results, if anything, underestimate the globalization effect on tolerance. Importantly, the Sargan test statistic also shows that the overidentifying restrictions are not rejected at conventional levels of significance.

We have also investigated other potential instruments of globalization used in the economics literature, e.g., population growth, language variables (English as an official language, the share of the population speaking English), geographic distance to New York and years of membership in the GATT/WTO. According to first-stage regression results and the results when including these variables in our baseline specification, none of these instruments are valid in our case. However, based on the results from the IV estimations using average globalization in neighboring countries and voting coincidence, we think it reasonable to regard globalization as causally related to the willingness to teach kids to be tolerant.

\footnotetext{
${ }^{28}$ The sample in our 2SLS estimation is reduced by one observation (Switzerland) due to a lack of data. This country did not become a full member of the United Nations until 2002.
} 
Table 4 Regression results using instrumental variables

\begin{tabular}{|c|c|c|c|c|c|c|c|c|c|c|}
\hline $\begin{array}{l}\text { Dependent } \\
\text { variable: }\end{array}$ & $\begin{array}{l}\text { Kids } \\
\text { tolerance }\end{array}$ & $\begin{array}{l}\text { Kids } \\
\text { tolerance }\end{array}$ & $\begin{array}{l}\text { Kids } \\
\text { tolerance }\end{array}$ & $\begin{array}{l}\text { Kids } \\
\text { tolerance }\end{array}$ & $\begin{array}{l}\text { Globalization } \\
\text { First stage }\end{array}$ & $\begin{array}{c}\text { Economic globalization } \\
\text { First stage }\end{array}$ & $\begin{array}{l}\text { Social globalization } \\
\text { First stage }\end{array}$ & $\begin{array}{l}\text { Kids tolerance } \\
\text { 2SLS }\end{array}$ & $\begin{array}{l}\text { Kids tolerance } \\
\text { 2SLS }\end{array}$ & $\begin{array}{l}\text { Kids tolerance } \\
\text { 2SLS }\end{array}$ \\
\hline Globalization & & $\begin{array}{c}0.357^{*} \\
{[0.191]}\end{array}$ & & & & & & $\begin{array}{l}0.792^{* *} \\
{[0.359]}\end{array}$ & & \\
\hline Economic globalization & & & $\begin{array}{c}0.243 \\
{[0.152]}\end{array}$ & & & & & & $\begin{array}{l}0.615^{* *} \\
{[0.270]}\end{array}$ & $0.864^{* *}$ \\
\hline Social globalization & & & & $\begin{array}{c}0.366^{* *} \\
{[0.175]}\end{array}$ & & & & & & [0.361] \\
\hline $\begin{array}{l}\text { Average globalization } \\
\text { in neighboring countries }\end{array}$ & $\begin{array}{c}0.267^{*} \\
{[0.141]}\end{array}$ & $\begin{array}{c}0.200 \\
{[0.131]}\end{array}$ & $\begin{array}{c}0.196 \\
{[0.140]}\end{array}$ & $\begin{array}{c}0.177 \\
{[0.120]}\end{array}$ & $\begin{array}{l}0.187^{*} \\
{[0.110]}\end{array}$ & $\begin{array}{l}0.290 * \\
{[0.154]}\end{array}$ & $\begin{array}{l}0.245^{*} \\
{[0.131]}\end{array}$ & & & \\
\hline Voting similarity & $\begin{array}{r}-4.719 \\
{[5.576]} \\
\end{array}$ & $\begin{array}{c}0.406 \\
{[5.580]} \\
\end{array}$ & $\begin{array}{c}-0.496 \\
{[5.479]} \\
\end{array}$ & $\begin{array}{c}-0.744 \\
{[5.348]}\end{array}$ & $\begin{array}{c}-14.347^{* *} \\
{[7.067]} \\
\end{array}$ & $\begin{array}{c}-17.356^{*} \\
{[9.839]} \\
\end{array}$ & $\begin{array}{l}-10.859 \\
{[8.373]}\end{array}$ & & & \\
\hline Observations & 65 & 65 & 65 & 65 & 65 & 65 & 65 & 65 & 65 & 65 \\
\hline First stage F-test & n.a & n.a & n.a & n.a & 4.25 & 3.90 & 3.01 & n.a & n.a & n.a \\
\hline First stage F-test (p-value) & n.a & n.a & n.a & n.a & 0.02 & 0.03 & 0.06 & n.a & n.a & n.a \\
\hline Sargan test (p-value) & п.a & n.a & n.a & n.a & n.a & n.a & n.a & 0.192 & 0.302 & 0.459 \\
\hline
\end{tabular}

Notes: Robust standard errors in parentheses. ${ }^{*}$ significant at $10 \%,{ }^{* *}$ significant at $5 \%,{ }^{* * *}$ significant at $1 \%$

Globalization, economic globalization and social globalization are instrumented by average level of globalization in neighboring countries in 1985, voting similarity with the United States in the UN General Assembly in 1995

and the same full set of control variables and country-group dummies as before. 


\subsection{Panel-Data Results}

We also examine what the relationship under study looks like when performing a fixed-effect panel-data analysis, with two or three observations for each country. Again we find that overall globalization relates positively to tolerance. As Table 5 shows, this result is in turn driven only by Social globalization, while Economic globalization is no longer significantly related to our outcome variable. However, when examining the five sub-components of Economic and Social globalization (see Box A1 in the Appendix), it becomes clear that less trade restrictions seem to encourage people to transmit the value of tolerance. With respect to Social globalization the driving force is Cultural proximity.

Table 5 Globalization and tolerance: panel-data results

\begin{tabular}{|c|c|c|c|c|c|c|c|c|c|}
\hline & (1) & (2) & (3) & (4) & (5) & (6) & (7) & (8) & (9) \\
\hline Globalization & $\begin{array}{c}0.434^{*} \\
{[0.243]}\end{array}$ & & & & & & & & \\
\hline Economic globalization & & $\begin{array}{c}0.191 \\
{[0.137]}\end{array}$ & & & & & & & \\
\hline Social globalization & & & $\begin{array}{l}0.264^{* *} \\
{[0.126]}\end{array}$ & & & & & & \\
\hline Political globalization & & & & $\begin{array}{c}0.022 \\
{[0.115]}\end{array}$ & & & & & \\
\hline Trade flows & & & & & $\begin{array}{c}0.008 \\
{[0.095]}\end{array}$ & & & & \\
\hline Trade restrictions & & & & & & $\begin{array}{c}0.220^{* *} \\
{[0.095]}\end{array}$ & & & \\
\hline Personal contact & & & & & & & $\begin{array}{c}-0.088 \\
{[0.351]}\end{array}$ & & \\
\hline Information flows & & & & & & & & $\begin{array}{c}0.102 \\
{[0.175]}\end{array}$ & \\
\hline Cultural proximity & & & & & & & & & $\begin{array}{c}0.090^{* *} \\
{[0.039]}\end{array}$ \\
\hline Real GDP per capita & $\begin{array}{c}1.547 \\
{[4.699]}\end{array}$ & $\begin{array}{c}3.100 \\
{[4.795]}\end{array}$ & $\begin{array}{c}1.095 \\
{[5.407]}\end{array}$ & $\begin{array}{c}3.326 \\
{[5.086]}\end{array}$ & $\begin{array}{c}4.614 \\
{[5.469]}\end{array}$ & $\begin{array}{c}1.592 \\
{[5.056]}\end{array}$ & $\begin{array}{c}3.225 \\
{[5.174]}\end{array}$ & $\begin{array}{c}2.350 \\
{[5.336]}\end{array}$ & $\begin{array}{c}1.741 \\
{[5.375]}\end{array}$ \\
\hline Education & $\begin{array}{c}0.014 \\
{[0.193]}\end{array}$ & $\begin{array}{c}0.073 \\
{[0.172]}\end{array}$ & $\begin{array}{c}0.046 \\
{[0.155]}\end{array}$ & $\begin{array}{c}0.066 \\
{[0.189]}\end{array}$ & $\begin{array}{c}0.057 \\
{[0.168]}\end{array}$ & $\begin{array}{c}0.065 \\
{[0.165]}\end{array}$ & $\begin{array}{c}0.075 \\
{[0.165]}\end{array}$ & $\begin{array}{c}0.067 \\
{[0.171]}\end{array}$ & $\begin{array}{c}0.051 \\
{[0.154]}\end{array}$ \\
\hline Urban population & $\begin{array}{c}0.410 \\
{[0.331]}\end{array}$ & $\begin{array}{c}0.358 \\
{[0.338]}\end{array}$ & $\begin{array}{c}0.469 \\
{[0.359]}\end{array}$ & $\begin{array}{c}0.309 \\
{[0.360]}\end{array}$ & $\begin{array}{c}0.291 \\
{[0.344]}\end{array}$ & $\begin{array}{c}0.245 \\
{[0.344]}\end{array}$ & $\begin{array}{c}0.335 \\
{[0.341]}\end{array}$ & $\begin{array}{c}0.324 \\
{[0.349]}\end{array}$ & $\begin{array}{c}0.497 \\
{[0.355]}\end{array}$ \\
\hline Young population & $\begin{array}{c}0.275 \\
{[0.216]}\end{array}$ & $\begin{array}{c}0.208 \\
{[0.215]}\end{array}$ & $\begin{array}{c}0.244 \\
{[0.223]}\end{array}$ & $\begin{array}{c}0.193 \\
{[0.212]}\end{array}$ & $\begin{array}{c}0.153 \\
{[0.221]}\end{array}$ & $\begin{array}{c}0.260 \\
{[0.222]}\end{array}$ & $\begin{array}{c}0.200 \\
{[0.209]}\end{array}$ & $\begin{array}{c}0.218 \\
{[0.225]}\end{array}$ & $\begin{array}{c}0.233 \\
{[0.211]}\end{array}$ \\
\hline Family values & $\begin{array}{c}18.921 \\
{[11.462]}\end{array}$ & $\begin{array}{c}\text { 20.736* } \\
{[11.625]}\end{array}$ & $\begin{array}{c}21.671^{*} \\
{[11.571]}\end{array}$ & $\begin{array}{c}21.088 * \\
{[12.466]}\end{array}$ & $\begin{array}{c}15.198 \\
{[12.066]}\end{array}$ & $\begin{array}{c}\text { 22.526* } \\
{[11.278]}\end{array}$ & $\begin{array}{c}\text { 21.815* } \\
{[11.953]}\end{array}$ & $\begin{array}{l}21.431 * \\
{[12.108]}\end{array}$ & $\begin{array}{c}22.123 * \\
{[11.439]}\end{array}$ \\
\hline Net income Gini & $\begin{array}{c}-0.304 \\
{[0.267]}\end{array}$ & $\begin{array}{c}-0.258 \\
{[0.243]}\end{array}$ & $\begin{array}{c}-0.286 \\
{[0.253]}\end{array}$ & $\begin{array}{c}-0.229 \\
{[0.249]}\end{array}$ & $\begin{array}{c}-0.238 \\
{[0.269]}\end{array}$ & $\begin{array}{c}-0.204 \\
{[0.246]}\end{array}$ & $\begin{array}{c}-0.240 \\
{[0.241]}\end{array}$ & $\begin{array}{c}-0.232 \\
{[0.244]}\end{array}$ & $\begin{array}{c}-0.301 \\
{[0.250]}\end{array}$ \\
\hline Civil liberities & $\begin{array}{c}2.023 \\
{[1.773]}\end{array}$ & $\begin{array}{c}1.685 \\
{[1.787]}\end{array}$ & $\begin{array}{c}2.195 \\
{[1.816]}\end{array}$ & $\begin{array}{c}2.120 \\
{[1.730]}\end{array}$ & $\begin{array}{c}1.794 \\
{[1.975]}\end{array}$ & $\begin{array}{c}2.212 \\
{[1.798]}\end{array}$ & $\begin{array}{c}2.082 \\
{[1.796]}\end{array}$ & $\begin{array}{c}2.251 \\
{[1.821]}\end{array}$ & $\begin{array}{c}2.035 \\
{[1.808]}\end{array}$ \\
\hline Political rights & $\begin{array}{c}-2.879 * * \\
{[1.199]}\end{array}$ & $\begin{array}{c}-2.629 * * \\
{[1.137]}\end{array}$ & $\begin{array}{c}-2.753^{* *} \\
{[1.176]}\end{array}$ & $\begin{array}{c}-2.622^{* *} \\
{[1.100]}\end{array}$ & $\begin{array}{c}-2.473^{* *} \\
{[1.151]}\end{array}$ & $\begin{array}{c}-2.606^{* *} \\
{[1.171]}\end{array}$ & $\begin{array}{c}-2.572^{* *} \\
{[1.130]}\end{array}$ & $\begin{array}{c}-2.669 * * \\
{[1.167]}\end{array}$ & $\begin{array}{c}-2.669^{* *} \\
{[1.147]}\end{array}$ \\
\hline Constant & $\begin{array}{c}-8.854 \\
{[47.310]} \\
\end{array}$ & $\begin{array}{c}-9.039 \\
{[46.015]} \\
\end{array}$ & $\begin{array}{c}-2.079 \\
{[51.772]} \\
\end{array}$ & $\begin{array}{c}0.210 \\
{[49.101]} \\
\end{array}$ & $\begin{array}{c}-3.159 \\
{[50.550]} \\
\end{array}$ & $\begin{array}{c}3.156 \\
{[47.437]} \\
\end{array}$ & $\begin{array}{c}3.186 \\
{[52.773]} \\
\end{array}$ & $\begin{array}{c}2.515 \\
{[49.862]}\end{array}$ & $\begin{array}{c}0.388 \\
{[50.886]} \\
\end{array}$ \\
\hline R-squared & 0.373 & 0.356 & 0.371 & 0.343 & 0.336 & 0.372 & 0.343 & 0.346 & 0.371 \\
\hline Number of countries & 64 & 64 & 64 & 64 & 63 & 64 & 64 & 64 & 64 \\
\hline Observations & 148 & 148 & 148 & 148 & 146 & 148 & 148 & 148 & 148 \\
\hline
\end{tabular}




\subsection{The Motivation of a Willingness to Teach Children Tolerance}

Theoretically, we posit that parents in general are both imperialistic and altruistic to varying degrees. Yet it is possible to gain partial knowledge whether one of the two suggested theoretical bases is predominant. As discussed in Section 2, in the imperialistic case, parents have certain preferences for tolerance and try to transmit these social attitudes, as they want the children to adopt the very same values. Therefore, if globalization affects parents' willingness to teach kids tolerance, it is through affecting the values of the parents. In the altruistic case, parents may very well value tolerance and globalization can also affect their level of tolerance, but this is not a necessary condition for them to think it important to teach their offspring to be tolerant: all that is required is the conviction that tolerance will be a good social attitude for the children to hold in the future. Keeping in mind that aggregate comparisons should be interpreted with caution, we try, in two ways, to ascertain which of these motivations that dominates.

First, we look at whether the effect of globalization to increase the willingness to teach children tolerance stems from globalization bringing about higher tolerance among adults. If it does not, this can be seen as ruling out the imperialistic motive. To study this in a very simple way, we regress the same set of explanatory variables as in Table 1 (for the crosssection case) and Table 5 (for the panel case) on two alternative dependent variables: tolerance among adults towards homosexuals and towards people of different race, collected from the World Values Survey and European Values Study. ${ }^{29}$ Both cross-sectional and panel results (available on request) suggest that globalization does not generally affect these tolerance measures. ${ }^{30}$ In other words, increasing economic, social and political integration does not seem to influence the contemporary level of tolerance in the adult population,

\footnotetext{
${ }^{29}$ Tolerance towards homosexuals refers to the share of the population in each country that does not pick "homosexuals" in answer to the question "On this list of various groups of people. Could you please mention any that you would not like to have as neighbors?”. Tolerance towards people of a different race refers to the share of the population that does not pick "people of a different race” in answer to the very same question.

${ }^{30}$ The only exception is the panel-data analysis on the relationship between economic globalization and tolerance towards people of different race. In line with our theoretical line of reasoning where economic globalization primarily is assumed to work through the imperialistic basis, this type of globalization is significantly and positively related to tolerance towards people of a different race.
} 
lending some support for an altruistic basis for the increase in parents' willingness to teach kids to be more tolerant that more globalization brings about.

At first glance, our results here may seem to imply that a willingness to teach kids tolerance does not result in actually higher tolerance (as they grow up and become adults). However, this is an incorrect conclusion. The fact that more globalization does not affect tolerance among adults does not rule out that the willingness of their parents (in turn likely affected by globalization) or other factors have made them tolerant - only that more current globalization does not increase their tolerance. This would not be surprising, since more tolerance from childhood could very well make adults less susceptible to the influence of more globalization on their tolerance levels. They would then already be quite tolerant.

Second, the former exercise looked at the role of altruism vs. imperialism in the marginal case, when globalization increases. It may still be, however, that the average level of tolerance among adults is high, which would suggest a role for imperialism in their overall attitudes and willingness to teach kids tolerance. To test this, we run regressions using the same specifications as in in Table 1 but also add the two new tolerance measures as explanatory variables. The idea is that imperialism can be rejected as an overall motivation, on average, if we do not get a positive and statistically significant estimate of the new tolerance variables. Table 6 presents the point estimates for the two tolerance measures across specifications. Columns 1-4 and 8-11 include the very same set of controls and dummies except globalization - as columns 1-4 of Table 1, while columns 5-7 and 12-14 also control for globalization.

As can be seen, the new tolerance measures quickly lose statistical significance as control variables are added. This suggests that the willingness to teach kids tolerance (our dependent variable) is not directly affected by the other two tolerance measures, which it would be had imperialism been the dominant motive. ${ }^{31}$ Again, this points at altruism as the primary explanation of the willingness to teach kids tolerance: Parents then care about their children and think they benefit from respecting and accepting others that are different in a globalizing world. It is not necessary, for them to have this willingness, that they themselves are tolerant.

\footnotetext{
${ }^{31}$ Interestingly, as noted above, this result would also reduce the potential problem of reverse causality.
} 
Table 6 Globalization and tolerance: cross-sectional results with new tolerance measures

\begin{tabular}{|c|c|c|c|c|c|c|c|c|c|c|c|c|c|c|}
\hline & (1) & (2) & (3) & (4) & (5) & (6) & (7) & (8) & (9) & (10) & (11) & (12) & (13) & (14) \\
\hline \multirow[t]{2}{*}{ Tolerance homosexuals } & $0.220 * * *$ & 0.069 & 0.076 & 0.096 & 0.031 & 0.051 & 0.052 & & & & & & & \\
\hline & {$[0.064]$} & {$[0.069]$} & {$[0.070]$} & {$[0.100]$} & {$[0.080]$} & {$[0.086]$} & {$[0.077]$} & & & & & & & \\
\hline \multirow[t]{2}{*}{ Tolerance different race } & & & & & & & & $0.606 * * *$ & 0.236 & 0.284 & 0.232 & 0.182 & 0.158 & 0.111 \\
\hline & & & & & & & & {$[0.198]$} & {$[0.212]$} & [0.205] & [0.259] & {$[0.204]$} & {$[0.220]$} & {$[0.200]$} \\
\hline \multirow[t]{2}{*}{ Globalization } & & & & & $0.514^{* *}$ & & & & & & & $0.518 * * *$ & & \\
\hline & & & & & [0.197] & & & & & & & {$[0.180]$} & & \\
\hline \multirow[t]{2}{*}{ Economic globalization } & & & & & & $0.305^{* *}$ & & & & & & & $0.306^{* *}$ & \\
\hline & & & & & & {$[0.147]$} & & & & & & & {$[0.147]$} & \\
\hline \multirow[t]{2}{*}{ Social globalization } & & & & & & & $0.504 * * *$ & & & & & & & $0.503^{* * *}$ \\
\hline & & & & & & & {$[0.187]$} & & & & & & & {$[0.180]$} \\
\hline Adj. $R^{2}$ & 0.180 & 0.323 & 0.324 & 0.383 & 0.468 & 0.444 & 0.505 & 0.187 & 0.331 & 0.338 & 0.383 & 0.479 & 0.448 & 0.504 \\
\hline Observations & 64 & 64 & 64 & 64 & 64 & 64 & 64 & 64 & 64 & 64 & 64 & 64 & 64 & 64 \\
\hline
\end{tabular}

Notes : Robust standard errors in parentheses

* significant at $10 \%$,** significant at $5 \%$,*** significant at $1 \%$

All estimated equations include a full set of control variables, a constant term and country-group dummies 


\section{Concluding Remarks}

Globalization is a multifaceted phenomenon that has been welcomed or decried on the basis of its perceived consequences. An increasing amount of studies make use of the relatively new KOF measure of globalization to produce more precise knowledge of the actual consequences. We add to this literature by studying whether economic, social and political globalization impacts the willingness of parents to teach tolerance to their children. This outcome variable is important since tolerance can be regarded as a valuable asset in any community, both because it creates an open and humane society in which people who are different are able to join in (which may be regarded as important in itself) and because it seems to make the economy function better by enabling a fuller use of human talent.

We primarily expect the effect of the three types of globalization to be positive. Economic globalization has the potential to make parents more tolerant, either through internalization following numerous interactions perceived to be beneficial with people who are different or through the realization that openness to such interactions are in their selfinterest. Tolerant parents are then likely to be willing to transmit tolerance to their children. The same goes for altruistic parents, even if they are not tolerant, when they consider it to be in the interest of the children to be open to people who are different. Social globalization means that values and ideas are transmitted more easily, through media, the Internet, travel, migration and other personal contacts, and to the extent that these are broadly liberal in character (e.g., through a Western cultural dominance), this can affect parents' tolerance and willingness to teach tolerance. They could also realize that it is in the best interest of their offspring to be able to be integrated with others who are different. Political globalization, lastly, concerns how nations interact with other nations and is probably not as influential on individual attitudes, but to the extent that parents notice how political ties and exchanges across borders are becoming more common and stronger, they could see this as a reason to instill tolerance in their offspring, to equip them better for an integrated world. Thus, our expectation is for positive effects of globalization. This is not to say that there cannot be negative effects as well, stemming from concerns about keeping culture unchanged and from fear of change. Ultimately, it is an empirical issue what the exact relationships look like.

To that end, we have conducted an empirical study encompassing up to 66 countries, and our expectation of positive relationships was confirmed: globalization seems to enhance the willingness to transmit tolerance to children. However, there are differences between the types of globalization. A cross-sectional analysis revealed that economic and social (but not 
political) globalization stand in a positive relationship to our outcome variable. A more detailed investigation showed that the economic factor of most importance is trade flows, whereas the social factors of relevance are cultural proximity and personal contacts.

Moreover, a panel-data analysis with country- and time-fixed effects largely confirmed these findings. According to these results, social globalization is the most important of the three globalization types for the transmission of tolerance, and in particular its sub-component cultural proximity. In the area of economic globalization, the factor absence of trade restrictions is also positively related to our dependent variable. Our findings lend support to a view of globalization as being able to bring about widely valued social effects, through influencing ideas about how to bring up children. These ideas seem to stem from an altruistic concern in parents, that instilling tolerance will equip children better for a future in a globalized world.

Despite using a panel-data specification with time and country fixed effects, as well as lagging globalization with respect to our dependent variable, it cannot be ruled out that some components of the KOF Index of Globalization could be affected by past or present levels of tolerance, generating an endogeneity problem with biased regression results. However, an instrumental-variable approach reassuringly suggests a causal relationship between globalization and the transmission of tolerance. 


\section{Appendix}

Box A1 The 2012 KOF Index of Globalization: Indices and variables weights

\section{A. Economic Globalization [36\%]}

i) Actual Flows (50\%)

Trade (percent of GDP) (21\%)

Foreign Direct Investment, stocks (percent of GDP) (28\%)

Portfolio Investment (percent of GDP) (24\%)

Income Payments to Foreign Nationals (percent of GDP) (27\%)

ii) Restrictions (50\%)

Hidden Import Barriers (24\%)

Mean Tariff Rate (27\%)

Taxes on International Trade (percent of current revenue) (26\%)

Capital Account Restrictions (23\%)

\section{B. Social Globalization [37\%]}

i) Data on Personal Contact (34\%)

Telephone Traffic (25\%)

Transfers (percent of GDP) (4\%)

International Tourism (26\%)

Foreign Population (percent of total population) (21\%)

International letters (per capita) (25\%)

ii) Data on Information Flows (35\%)

Internet Users (per 1000 people) (33\%)

Television (per 1000 people) (36\%)

Trade in Newspapers (percent of GDP) (32\%)

iii) Data on Cultural Proximity (31\%)

Number of McDonald’s Restaurants (per capita) (44\%)

Number of Ikea (per capita) (45\%)

Trade in books (percent of GDP) (11\%)

\section{Political Globalization [26\%]}

Embassies in Country (25\%)

Membership in International Organizations (28\%)

Participation in U.N. Security Council Missions (22\%)

International Treaties (25\%)

Source: Dreher et al. (2008). 
Table A1 Descriptive statistics

\begin{tabular}{|c|c|c|c|c|c|c|}
\hline $\begin{array}{l}\text { Variable } \\
\end{array}$ & Description & $\begin{array}{l}\text { Source } \\
\end{array}$ & Mean & Std. dev. & Min & Max \\
\hline Kids tolerance & $\begin{array}{l}\text { Share of the population answering "Important" to the quality } \\
\text { "Tolerance" when being asked the question "Here is a list of qualities that } \\
\text { children can be encouraged to learn at home. Which, if any, do you } \\
\text { consider to be especially important?" }\end{array}$ & $\begin{array}{l}\text { World Values Survey (2012) and } \\
\text { European Value Study (2012) }\end{array}$ & 71.12 & 11.45 & 50.37 & 93.62 \\
\hline Globalization & Aggregate globalization index & Dreher et al. (2008a) & 60.80 & 17.01 & 26.26 & 90.30 \\
\hline Economic globalization & Economic globalization & Dreher et al. (2008a) & 58.37 & 17.96 & 23.32 & 94.81 \\
\hline Social globalization & Social globalization & Dreher et al. (2008a) & 53.06 & 22.58 & 12.70 & 90.93 \\
\hline Political globalization & Political globalization & Dreher et al. (2008a) & 75.71 & 18.22 & 21.40 & 98.78 \\
\hline Trade flows & Actual trade flows & Dreher et al. (2008a) & 53.88 & 19.29 & 15.85 & 99.55 \\
\hline Trade restrictions & Trade restrictions & Dreher et al. (2008a) & 63.57 & 21.62 & 16.93 & 94.37 \\
\hline Personal contact & Personal contact & Dreher et al. (2008a) & 52.06 & 22.06 & 10.90 & 93.78 \\
\hline Information flows & Information flows & Dreher et al. (2008a) & 59.40 & 22.07 & 13.60 & 90.77 \\
\hline Cultural proximity & Cultural proximity & Dreher et al. (2008a) & 46.96 & 29.99 & 1.25 & 96.50 \\
\hline Real GDP per capita & Log real GDP per capita, constant prices & Heston et al. (2009) & 8.98 & 1.21 & 5.88 & 10.81 \\
\hline Education & Share of population that have completed secondary education & Barro and Lee (2010) & 22.68 & 12.11 & 0.71 & 47.36 \\
\hline Young population & Share of population 15 years or younger & WDI (World Bank, 2011) & 44.97 & 20.83 & 21.87 & 101.33 \\
\hline Urban population & $\begin{array}{l}\text { Share of population living in urban areas } \\
\text { Measure on the importance of family. Average of three variables } \\
\text { measuring parents' duties and responsibilitites, }\end{array}$ & WDI (World Bank, 2011) & 61.59 & 21.33 & 9.60 & 100 \\
\hline Family values & $\begin{array}{l}\text { how much children should respect elderly, and how important family is in } \\
\text { life (see Alesina and Giuliano, 2009) }\end{array}$ & $\begin{array}{l}\text { World Values Survey (2012) and } \\
\text { European Value Study (2012) }\end{array}$ & 82.80 & 9.34 & 58.63 & 96.17 \\
\hline Religious fractionalization & Index of religious fractionalization & Alesina et al. (2003) & 0.43 & 0.24 & 0.003 & 0.86 \\
\hline Ethnic fractionalization & Index of ethnic fractionalization & Alesina et al. (2003) & 0.37 & 0.23 & 0.002 & 0.93 \\
\hline Religion-Catholic & Percent Catholic & La Porta et al. (1999) & 36.46 & 37.40 & 0 & 96.9 \\
\hline Religion - Muslim & $\begin{array}{l}\text { Percent Muslim } \\
\text { Civil liberties (measured from } 1 \text { to } 7 \text {, where } 7 \text { is the lowest }\end{array}$ & La Porta et al. (1999) & 12.96 & 28.16 & 0 & 99.4 \\
\hline Civil liberties & $\begin{array}{l}\text { and } 1 \text { the highest degree) } \\
\text { Political rights (measured from } 1 \text { to } 7 \text {, where } 7 \text { is the lowest }\end{array}$ & Freedom House (2012) & 2.94 & 1.66 & 1 & 7 \\
\hline Political rights & and 1 the highest degree) & Freedom House (2012) & 2.58 & 1.83 & 1 & 7 \\
\hline $\begin{array}{l}\text { Net income Gini } \\
\text { Average globalization }\end{array}$ & Gini coefficient measuring net income inequality & SWIID 2010 (Solt, 2010) & 35.09 & 9.17 & 20.22 & 62.84 \\
\hline in neighbouring countries & Average globalization in neighbouring countries in 1985 & Dreher et al. (2008a) & 49.2 & 15.69 & 23.34 & 79.11 \\
\hline Voting similarity & Voting similarity with the US in the UN General Assembly in 1995 & Strezhnev and Voeten (2013) & 0.46 & 0.14 & 0.22 & 1 \\
\hline Tolerance homosexuals & $\begin{array}{l}\text { Share of the population that does not pick homosexuals in answering to } \\
\text { the question "On this list are various groups of people. Could you please } \\
\text { mention any that you would not like to have as neighbours?" } \\
\text { Share of the population that does not pick "people of different race" in } \\
\text { answering to the question "On this list are various groups of people. }\end{array}$ & $\begin{array}{l}\text { World Values Survey (2012) and } \\
\text { European Value Study (2012) }\end{array}$ & 57.01 & 26.40 & 0.40 & 96.01 \\
\hline Tolerance different race & $\begin{array}{l}\text { Could you please mention any that you would not like to have as } \\
\text { neighbours?" }\end{array}$ & $\begin{array}{l}\text { World Values Survey (2012) and } \\
\text { European Value Study (2012) }\end{array}$ & 85.11 & 10.81 & 48.58 & 98.60 \\
\hline East Asia & Dummy for East Asian countries & WDI (World Bank, 2011) & 0.16 & 0.37 & 0 & 1 \\
\hline Europe & Dummy for European countries & WDI (World Bank, 2011) & 0.48 & 0.5 & 0 & 1 \\
\hline Latin America & Dummy for Latin American countries & WDI (World Bank, 2011) & 0.14 & 0.35 & 0 & 1 \\
\hline Middle East & Dummy for countries in Middle East & WDI (World Bank, 2011) & 0.06 & 0.25 & 0 & 1 \\
\hline North America & Dummy for Noth American countries & WDI (World Bank, 2011) & 0.03 & 0.18 & 0 & 1 \\
\hline South Asia & Dummy for South Asian countries & WDI (World Bank, 2011) & 0.02 & 0.13 & 0 & 1 \\
\hline Sub-Saharan Africa & Dummy for countries in sub-Saharan Africa & WDI (World Bank, 2011) & 0.11 & 0.32 & 0 & 1 \\
\hline
\end{tabular}


Table A2 Country list

\begin{tabular}{llllll}
\hline \hline Algeria & Denmark & Indonesia & Mexico & Russian Fed. & Trinidad \& Tobago \\
Argentina & Egypt & Ireland & Moldova & Singapore & Turkey \\
Australia & Estonia & Italy & Morocco & Slovak Rep. & Uganda \\
Austria & Finland & Japan & Netherlands & Slovenia & Ukraine \\
Belgium & France & Jordan & New Zealand & South Africa & United Kingdom \\
Brazil & Germany & Kyrgyz Rep. & Norway & South Korea & United States \\
Bulgaria & Ghana & Latvia & Peru & Spain & Uruguay \\
Canada & Greece & Lithuania & Philippines & Sweden & Venezuela \\
Chile & Guatemala & Luxembourg & Poland & Switzerland & Vietnam \\
China & Hungary & Malaysia & Portugal & Tanzania & Zambia \\
Czech Rep. & India & Mali & Romania & Thailand & Zimbabwe \\
\hline
\end{tabular}




\section{References}

Akerlof, George A. and Rachel E. Kranton (2000). “Economics and Identity.” Quarterly Journal of Economics, 115(3): 715-753.

Alesina, Alberto, Arnaud Devleeschauwer, William Easterly, Sergio Kurlat and Romain Wacziarg (2003).

"Fractionalization.” Journal of Economic Growth, 8(2): 155-194.

Alesina, Alberto and Paola Giuliano (2010). “The Power of the Family.” Journal of Economic Growth, 15(2): 93-125.

Andersen, Robert and Tina Fetner (2008). "Economic Inequality and Intolerance: Attitudes toward Homosexuality in 35 Democracies.” American Journal of Political Science, 52(4): 942-958.

A. T. Kearney/Foreign Policy Magazine (2003). “Measuring Globalization: Who’s Up, Who’s Down?” Foreign Policy, 134: 60-72.

Armstrong, Adrienne (1981). “The Political Consequences of Economic Dependence.” Journal of Conflict Resolution, 25(3): 401-428.

Atkinson, Anthony B. (1997). “Bringing Income Distribution in from the Cold.” Economic Journal, 107(441): 297-321.

Barro, Robert J. and Jong-Wha Lee (2010). “A New Data Set of Educational Attainment in the World, 19502010.” Working Paper 15902, NBER, Cambridge, MA.

Battu, Harminer and Yves Zenou (2010). ”Oppositional Identities and Employment for Ethnic Minorities: Evidence from England.” Economic Journal, 120(542): F52-F71.

Bauman, Zygmunt (1998). Globalisation: The Human Consequences. Cambridge: Polity Press.

Becker, Gary S. (1971). The Economics of Discrimination. Chicago: University of Chicago Press.

Berggren, Niclas and Christian Bjørnskov (2011). "Is the Importance of Religion in Daily Life Related to Social Trust? Cross-Country and Cross-State Comparisons.” Journal of Economic Behavior \& Organization, 80(3): 459-480.

Berggren, Niclas and Mikael Elinder (2012). “Is Tolerance Good or Bad for Growth?” Public Choice, 150(1-2): 283-308.

Berggren, Niclas, Mikael Elinder and Henrik Jordahl (2008). “Trust and Growth: A Shaky Relationship.” Empirical Economics, 35(2): 251-274.

Berggren, Niclas and Henrik Jordahl (2006). “Free to Trust: Economic Freedom and Social Capital.” Kyklos, 59(2): 141-169.

Berggren, Niclas and Therese Nilsson (2012). “Does Economic Freedom Foster Tolerance?” Kyklos, 66(2): 177207.

Bergh, Andreas and Martin Karlsson (2009). “Government Size and Growth: Accounting for Economic Freedom and Globalization.” Public Choice, 142(1-2): 195-213.

Bergh, Andreas and Therese Nilsson (2010a). "Do Economic Liberalization and Globalization Increase Income Inequality?” European Journal of Political Economy, 26(4): 488-505.

Bergh, Andreas and Therese Nilsson (2010b). "Good for Living? On the Relation between Globalization and Life Expectancy.” World Development, 38(9): 1191-1203.

Bhagwati, Jagdish (2004). In Defense of Globalization. Oxford: Oxford University Press. 
Bisin, Alberto, Giorgio Topa and Thierry Verdier (2004). “Cooperation as a Transmitted Cultural Trait.” Rationality and Society, 16(4): 477-507.

Bisin, Alberto and Thierry Verdier (2000). "Beyond the Melting Pot: Cultural Transmission, Marriage and the Evolution of Ethnic and Religious Traits.” Quarterly Journal of Economics, 115(3): 955-988.

Bisin, Alberto and Thierry Verdier (2001). "The Economics of Cultural Transmission and the Dynamics of Preferences.” Journal of Economic Theory, 97(2): 298-319.

Bisin, Alberto and Thierry Verdier (2011). “The Economics of Cultural Transmission and Socialization.” In Jess Benhabib, Alberto Bisin and Matthew O. Jackson (Eds.), The Handbook of Social Economics. Amsterdam: North-Holland: 339-416.

Bjørnskov, Christian (2007). “Determinant of Generalized Trust: A Cross-Country Comparison.” Public Choice, 130(1-2): 1-21.

Bjørnskov, Christian, Axel Dreher and Justina Fischer (2008). "Cross-Country Determinants of Life Satisfaction: Exploring Different Determinants Across Groups in Society.” Social Choice and Welfare, 30(1): 119-173.

Black, Sandra E. and Elizabeth Brainerd (2004). ”Importing Equality? The Impact of Globalization on Gender Discrimination.” Industrial and Labor Relations Review, 57(4): 540-559.

Bogt, Tom ter, Quinten Raaijmakers and Frits van Wel (2005). "Socialization and Development of the Work Ethic Among Adolescents and Young Adults.” Journal of Vocational Behavior, 66(3): 420-437.

Bowles, Samuel (1998). "Endogenous Preferences: The Cultural Consequences of Markets and Other Economic Institutions.” Journal of Economic Literature, 36(1): 75-111.

Bradshaw, Matt and Christopher G. Ellison (2008). "Do Genetic Factors Influence Religious Life? Findings from a Behavior Genetic Analysis of Twin Siblings.” Journal for the Scientific Study of Religion, 47(4): 529544.

Butler, Jeffrey, Paola Giuliano and Luigi Guiso (2012). “Trust, Values and False Consensus.” NBER Working Paper No. 18460, National Bureau of Economic Research, Cambridge, MA.

Cesarini, David, Christopher T. Dawes, Magnus Johannesson, Paul Lichtenstein and Björn Wallace (2009). “Genetic Variation in Preferences for Giving and Risk Taking.” Quarterly Journal of Economics, 124(2): 809842.

Chong, Alberto and Eliana La Ferrara (2009). “Television and Divorce: Evidence from Brazilian Novelas.” Journal of the European Economic Association, 7(2-3): 458-468.

Cho, Seo-Yound (2013). "Integrating Equality: Globalization, Women's Rights, and Human Trafficking.” International Studies Quarterly, forthcoming.

Christopoulou, Rebekka, Ahmed Jaber and Dean R. Lillard (2013). “The Inter-Generational and Social Transmission of Cultural Traits: Theory and Evidence from Smoking Behavior.” NBER Working Paper No. 19304, NBER, Cambridge, MA.

Coneus, Katja, Manfred Laucht and Karsten Reuß (2012). “The Role of Parental Investments for Cognitive and Non-Cognitive Skill Formation - Evidence for the First 11 Years of Life.” Economics \& Human Biology, 10(2): 189-209.

Coneus, Katja and Maresa Sprietsma (2009). “Intergenerational Transmission of Human Capital in Early Childhood.” ZEW Discussion Paper No. 09-038, Centre for European Economic Research, Mannheim, Germany.

Congdon Fors, Heather (2012). “Social Globalization and Child Labor.” Working Paper No. 533, School of Business, Economics and Law, University of Gothernburg, Gothenburg, Sweden. 
Corneo, Giacomo and Olivier Jeanne (2009). “A Theory of Tolerance.” Journal of Public Economics, 93(5-6), 691-702.

Cowen, Tyler (2002). Creative Destruction: How Globalization Is Changing the World's Cultures. Princeton: Princeton University Press.

Das, Jayoti, Cassandra DiRienzo and Thomas Tiemann (2008). “A Global Tolerance Index.” Competitiveness Review, 18(3): 192-205.

DellaVigna, Stefano and Ethan Kaplan (2007). “The Fox News Effect: Media Bias and Voting.” Quarterly Journal of Economics, 122(3): 1187-1234.

de Soysa, Indra and Krishna Chaitanya Vadlamannati (2011). “Does Being Bound Together Suffocate, or Liberate? The Effects of Economics, Social, and Political Globalization on Human Rights, 1981-2005.” Kyklos, 64(1): 20-53.

Doepke, Matthias and Fabrizio Zilibotti (2012). "Parenting with Style: Altruism and Paternalism in Intergenerational Preference Transmission.” Working Paper No. 419, Department of Economics, University of Zurich, Switzerland.

Dohmen, Thomas, Armin Falk, David Huffman and Uwe Sunde (2012). "The Intergenerational Transmission of Risk and Trust Attitudes.” Review of Economic Studies, 79(2): 645-677.

Dreher, Axel (2006a). "Does Globalization Affect Growth? Evidence from a New Index of Globalization.” Applied Economics, 38(10): 1091-1110.

Dreher, Axel (2006b). “The Influence of Globalization on Taxes and Social Policy: An Empirical Analysis for OECD Countries.” European Journal of Political Economy, 22(1): 179-201.

Dreher, Axel, Martin Gassebner and Lars-H. R. Siemers (2012). “Globalization, Economic Freedom and Human Rights.” Journal of Conflict Resolution, 56(3): 516-546.

Dreher, Axel and Noel Gaston (2008). “Has Globalization Increased Inequality?” Review of International Economics, 16(3): 516-536.

Dreher, Axel, Noel Gaston and Pim Martens (2008a). Measuring Globalization - Gauging its Consequences. New York: Springer.

Dreher, Axel, Peter Nunnenkamp and Rainer Thiele (2008b). "Does U.S. Aid Buy UN General Assembly Votes? A Disaggregated Analysis.” Public Choice, 136(1-2): 139-164.

Dreher, Axel, Jan-Egbert Sturm and Heinrich W. Ursprung (2008). “The Impact of Globalization of the Composition of Government Expenditures: Evidence from Panel Data.” Public Choice, 134(3-4): 263-292.

Dreher, Axel and Jan-Egbert Sturm (2012). "Do the IMF and the World Bank Influence Voting in the UN General Assembly?” Public Choice, 151(1-2): 363-397.

Eichengreen, Barry and David Leblang (2008). “Democracy and Globalization.” Economics \& Politics, 20(3): 289-334.

Ermisch, John and Diego Gambetta (2010). “Do Strong Family Ties Inhibit Trust?” Journal of Economic Behavior \& Organization, 75(3): 365-376.

European Value Study (2012). Online Database. http://www.europeanvaluesstudy.eu (accessed 10.02.2012).

Férnandez, Raquel (2011). “Does Culture Matter?” In Jess Benhabib, Alberto Bisin and Matthew O. Jackson (Eds.), The Handbook of Social Economics. Amsterdam: North-Holland: 481-510. 
Fernández, Raquel, Alessandra Fogli and Claudia Olivetti (2004). "Mothers and Sons: Preference Formation and Female Labor Force Dynamics.” Quarterly Journal of Economics, 119(4): 1249-1299.

Fischer, Stanley (2003). “Globalization and Its Challenges.” American Economic Review, 93(2): 1-30.

Florida, Richard (2002). “Bohemia and Economic Geography.” Journal of Economic Geography, 2(1): 55-71.

Florida, Richard (2003). “Cities and the Creative Class.” City \& Community, 2(1): 3-19.

Florida, Richard, Charlotta Mellander and Kevin Stolarick (2008). "Inside the Black Box of Regional Development - Human Capital, the Creative Class and Tolerance.” Journal of Economic Geography, 8(5): 615649.

Freedom House (2012). Online Database. http://www.freedomhouse.org (accessed 10.02.2012).

Friedman, Benjamin M. (2005). The Moral Consequences of Economic Growth. New York: Alfred A. Knopf.

Gassebner, Martin, Noel Gaston, and Michael J. Lamla (2011). “The Inverse Domino Effect: Are Economic Reforms Contagious?” International Economic Review, 52(1): 183-200.

Gentzkow, Matthew and Jesse Shapiro (2004). "Media, Education and Anti-Americanism in the Muslim World.” Journal of Economic Perspectives, 18(3): 117-133.

Guillén, Mauro F. (2001). “Is Globalization Civilizing, Destructive or Feeble? A Critique of Five Key Debates in the Social Science Literature.” Annual Review of Sociology, 27: 235-260.

Guiso, Luigi, Paola Sapizenza and Luigi Zingales (2009). “Cultural Biases in Economic Exchange?” Quarterly Journal of Economics, 124(3): 1095-1131.

Hatemi, Peter K., John R. Alford, John R. Hibbing, Nicholas G. Martin and Lindon J. Eaves (2008). "Is There a 'Party' in Your Genes?” Political Research Quarterly, 62(3): 584-600.

Heineck, Guido and Regina T. Riphahn (2007). "Intergenerational Transmission of Educational Attainment in Germany: The Last Five Decades.” Discussion papers No. 738, German Institute for Economic Research, Berlin.

Heinrich, Joseph, Robert Boyd, Samuel Bowles, Colin Camerer, Ernst Fehr, Herbert Gintis and Richard McElreath (2001). “Cooperation, Reciprocity and Punishment in Fifteen Small-Scale Societies.” American Economic Review, 91(2): 73-78.

Hessami, Zohal (2011). “Globalization’s Winners and Losers - Evidence from Life Satisfaction Data, 19752001.” Economics Letters, 112(3): 250-253.

Heston, Alan, Robert Summers and Bettina Aten (2009). “Penn World Table Version 6.3.” Statistical Table, Center for International Comparison of Production, Income and Prices, University of Pennsylvania, Philadelphia, PA.

Holton, Robert (2000). “Globalization’s Cultural Consquences.” Annals of the American Academy of Political and Social Science, 570(1): 140-152.

Huisman, Janine and Jeron Smits (2009). "Effects of Household- and District-Level Factors on Primary School Enrolment in 30 Developing Countries.” World Development, 37(1): 179-193.

Inglehart, Ronald (2000). “Globalization and Postmodern Values.” Washington Quarterly, 23(1): 215 -228.

Inglehart, Ronald F., Svetlana Borinskaya, Anna Cotter, Jaanus Harro, Ronald C. Inglehart, Eduard Ponarin and Christian Welzel (2013). “Genes, Security, Tolerance and Happiness.” Working Paper No. BRP 31/SOC, National Research University Higher School of Economics (HSE), Moscow.

Inglehart, Ronald and Paul R. Abramson (1999). “Measuring Postmaterialism.” American Political Science Review, 93(3): 665-677. 
Jaspers, Eva (2008). “Transmission of Inteolerance: Parent Child Attitude Similarities.” In Intolerance Over Time: Macro and Micro Level Questions on Attitudes Towards Euthanasia, Homosexuality and Ethnic Minorities. PhD Dissertation, Radbouden University, Nijmegen, The Netherlands.

Jensen, Robert and Emily Oster (2009). “The Power of TV: Cable Television and Women’s Status in India.” Quarterly Journal of Economics, 124(3): 1057-1094.

Klosko, George (2000). Democratic Procedures and Liberal Consensus. Oxford: Oxford University Press.

Koenig, Laura B., Matt McGue, Robert F. Krueger and Thomas J. Bouchard Jr. (2005). “Genetic and Environmental Influences on Religiousness: Findings for Retrospective and Current Religiousness Ratings.” Journal of Personality, 73(2): 472-488.

Koster, Ferry (2007). "Globalization, Social Structure, and the Willingness to Help Others: A Multilevel Analysis Across 26 Countries.” European Sociological Review, 23(4): 537-551.

La Ferrara, Eliana, Alberto Chong and Suzanne Duryea (2012). "Soap Operas and Fertility: Evidence from Brazil.” American Economic Journal: Applied Economics, 4(4): 1-31.

La Porta, Rafael, Florencio Lopez-de-Silanes, Andrei Shleifer and Robert W. Vishny (1999). "The Quality of Government.” Journal of Law, Economics, and Organization, 15(1): 222-279.

Ljunge, Martin (2012). “Trust Issues: Evidence from Second Generation Immigrants.” Working Paper No. 946, Research Institute of Industrial Economics (IFN), Stockholm.

Lockwood, Ben and Michela Redoano (2005). “The CSGR Globalisation Index: An Introductory Guide.” Working Paper 155/04, Centre for the Study of Globalisation and Regionalisation, University of Warwick, Warwick, UK.

Machida, Satoshi (2012). “Does Globalization Render People More Ethnocentric? Globalization and People’s Views on Culture.” American Journal of Economics and Sociology, 71(2): 436-469.

McGranahan, David A. and Timothy Wojan (2007). "Recasting the Creative Class to Examine Growth Processes in Rural and Urban Counties.” Regional Studies, 41(2): 197-216.

Meinhard, Stephanie and Niklas Potrafke (2012). “The Globalization-Welfare State Nexus Reconsidered.” Review of International Economics, 20(2): 271-287.

Mendez, Michelle A. and Barry M. Popkin (2004). "Globalization, Urbanization and Nutritional Change in the Developing World.” Journal of Agricultural and Development Economics, 1(2): 220-241.

Mokyr, Joel (1990). The Lever of Riches: Technological Creativity and Economic Progress. Oxford: Oxford University Press.

O’Loughlin, John, Lynn Staeheli and Edward Greenberg (Eds.) (2004). Globalization and Its Outcomes. New York: The Guilford Press.

Ottaviano, Gianmarco I. P. and Giovanni Peri (2006). “The Economic Value of Cultural Diversity: Evidence from U.S. Cities.” Journal of Economic Geography, 6(1): 9-44.

Potrafke, Niklas (2013). “The evidence on globalization” Memo University of Munich, ifo Institute, August 2013

Potrafke, Niklas and Heinrich W. Urspring (2012). "Globalization and Gender Equality in the Course of Development.” European Journal of Political Economy, 28(4): 399-413.

Putnam, Robert D. (2000). Bowling Alone: The Collapse and Revivial of American Community. New York: Simon \& Schuster. 
Richardson, Neil R. and Charles W. Kegley (1980). “Trade Dependence and Foreign Policy Compliance.” International Studies Quarterly, 24(2): 191-222.

Rodrik, Dani (2007). One Economics, Many Recipes: Globalization, Institutions and Economic Growth. Princeton: Princeton University Press.

Rosenau, James N. (2003). Distant Proximities: Dynamics Beyond Globalization. Princeton: Princeton University Press.

Sandholtz, Wayne and Mark M. Gray (2003). “International Integration and National Corruption.” International Organization, 57(4): 761-800.

Scheve, Kenneth and Matthew J. Slaughter (2004). "Economic Insecurity and the Globalization of Production.” American Journal of Political Science, 48(4): 662-674.

Settle, Jaime E., Christopher T. Dawes and James H. Fowler (2009). “The Heritability of Partisan Attachment.” Political Research Quarterly, 62(3): 601-613.

Sklair, Leslie (2001). The Transnational Capitalist Class. Oxford: Blackwell.

Solt, Frederick (2010). “Standardizing the World Income Inequality Database.” Social Science Quarterly, 90(2): 231-242.

Spitz, Laura (2004). “At the Intersection of North American Free Trade and Same-Sex Marriage.” UCLA Journal of International Law and Foreign Affairs, 9: 163.

Stiglitz, Joseph E. (2003). Globalization and Its Discontents. New York: W. W. Norton \& Co.

Strezhnev, Anton, and Erik Voeten (2013). "United Nations General Assembly Voting Data", http://hdl.handle.net/1902.1/12379.

Tabellini, Guido (2008a). “Institutions and Culture.” Journal of the European Economic Association, 6(2-3): 255-294.

Tabellini, Guido (2008b). “The Scope of Cooperation: Values and Incentives.” Quarterly Journal of Economics, 123(3): 905-950.

Tabellini, Guido (2010). “Culture and Institutions: Economic Development in the Regions of Europe.” Journal of the European Economic Association, 8(4): 677-716.

Tsai, Ming-Chang (2007). “Does Globalization Affect Human Well-Being?” Social Indicators Research, 81(1): 103-126.

Vollebergh, Wilma, Jurjen Iedema and Quinten Raaijmakers (1999). “The Intergenerational Transmission of Cultural and Economic Conservatism.” In Hans De Witte and Peer Scheepers (Eds.), Ideology in the Low Countries: Trends, Models and Lacunae. Assen: Van Gorcum: 51-68.

World Bank (2011). World Development Indicators. Washington, DC: World Bank.

World Values Survey (2012). Online Database. http://www.worldvaluessurvey.org (accessed 10.02.2012).

Wilhelm, Mark O., Eleanor Brown, Patrick M. Rooney and Richard Steinberg (2008). “The Intergenerational Transmission of Generosity.” Journal of Public Economics, 92(10-11): 2146-2156. 